\title{
The Generational and Institutional Sources of the Global Decline in Voter Turnout
}

\author{
Filip Kostelka* \& André Blais ${ }^{\dagger}$
}

\begin{abstract}
Why has voter turnout been declining in democracies all over the world? This article draws on findings from micro-level studies and theorizes two explanations: generational change and a rise in the number of elective institutions. The empirical section tests these hypotheses along with other explanations proposed in the literature (shifts in party/candidate competition, voting age reforms, weakening group mobilization, income inequality, and economic globalization). We conduct two analyses. The first analysis employs an original data set covering all post-1945 democratic national elections. The second studies individual-level data from the Comparative Study of Electoral Systems and American, British, and Canadian national election studies. The results strongly support the generational change and elective institutions hypotheses, which account for most of the decline. These findings have important implications for a better understanding of the current transformations of representative democracy and the challenges it faces.
\end{abstract}

This paper can be cited as follows: Kostelka, Filip, and André Blais. forthcoming. "The Generational and Institutional Sources of the Global Decline in Voter Turnout". World Politics.

Acknowledgment: We would like to thank Damien Bol, Ruth Dassonneville, Jean-François Daoust, Anja Durovic, Robert Johns, Ian McAllister, Shane P. Singh, Dietlind Stolle, Vincent Tiberj, and World Politics editors and reviewers for their insightful comments on earlier drafts of this paper.

*Department of Government, University of Essex, email: filip.kostelka@essex.ac.uk

${ }^{\dagger}$ Department of Political Science, University of Montreal; email: andre.blais@ umontreal.ca 
'Politicians Dogged by Voter Discontent.' 'Apathy Growing in Many Voters.' 'Voter Turnout a Vexing Problem.' 'Record Low Voter Turnout Expected in National Election.' 'Concerns over Low Voter Turnout.' 'Low Voter Turnout Puzzles Analysts.' 'Voter Turnout Lowest in 20 Years Due to Political Apathy.' These post-2000 headlines from leading media all over the world ${ }^{1}$ illustrate how declining voter turnout has become a global phenomenon in contemporary democracies. While in the late 1960 s, typically over $77 \%$ citizens voted in national, legislative and presidential, elections, the global average voting rate fell to $67 \%$ after $2010 .^{2}$ Figure 1 below shows the gradual nature of this decline. ${ }^{3}$ Though democracy expanded across countries, ${ }^{4}$ electoral participation faded within them. This is both problematic and puzzling.

The global decline is problematic since when voter turnout is low, economically and socially disadvantaged groups tend to abstain more, which questions the principle of democratic equality. ${ }^{5}$ Moreover, there is evidence that low voter turnout introduces a bias in public policy, reduces government responsiveness, and favors clientelism and patronage over programmatic party competition. ${ }^{6}$

For a number of reasons, the global decline in voter turnout is puzzling. First, it occurred despite the presence of factors that could have increased and not decreased participation such as a general rise in education. ${ }^{7}$ Second, the most intuitive explanation, heavily present in journalistic accounts, that attributes the decline to citizen discontent is not supported by available micro-level and macro-level evidence (see page 4 below for an overview). Third, the decline is not the result of the five-fold expansion of the pool of electoral democracies by low-turnout countries. In those countries that have held elections continuously since the 1940s, voting rates fell by as much (see Figure 1). ${ }^{8}$

Political scientists have offered a large number of alternative accounts. The most prominent hypotheses, which we discuss in depth in the next section, pertain to a decline in group mobilization, transformation of party competition, voting age reforms, income inequality, economic globalization, and generational change. However, the current state of the literature does not clearly solve the puzzle of voter decline as existing studies usually theorize and test the different hypotheses in isolation and on a limited number of elections. Moreover, they rarely quantify the relative weight of the various contributions to the decline. In this article, we draw on the valuable insights from existing studies and propose a comprehensive investigation of the global rise in electoral absten-

\footnotetext{
${ }^{1}$ Canada, Great Britain, Germany or Sweden, Mozambique, Senegal, and South Korea.

${ }^{2}$ Unless stated otherwise, voter turnout in this manuscript corresponds to the share of registered voters who cast a ballot.

${ }^{3}$ The data for this figure are presented in the Data and Methods section below.

${ }^{4}$ Huntington 1991.

${ }^{5}$ Lijphart 1997; Dassonneville and Hooghe 2017. There are a few exceptions to this otherwise consistent relationship in new democracies, see Kasara and Suryanarayan 2015.

${ }^{6}$ Martin and Claibourn 2013; Avery 2015; Nooruddin and Simmons 2015; Aggeborn 2016. See Blais, Dassonneville, and Kostelka 2020 for an overview.

${ }^{7}$ Brody 1978; Teixeira 1992.

${ }^{8}$ Figure 1 suggests that the global decline started already in the 1950s. However, as the trend in the group of continuous democracies demonstrates, the 1940s-1960s difference stems mostly from the emergence of new democratic countries.
} 
tion.

From the theoretical standpoint, we critically reassess the strengths and weaknesses of the competing explanations. We argue in favor of two hypotheses which we further develop: generational change and a multiplication of elective institutions. The generational explanation builds on the rich literature on value change inspired by modernization theory. ${ }^{9}$ We postulate that new generations born in relative material affluence have different values, less conducive to participation, than generations born in economically less favorable contexts. The increasing share of these new generations in the electorate gradually reduces the aggregated voting rates. The second hypothesis is based on the observation that democracies have witnessed a substantial increase in the total number of elections and referendums in which citizens may participate. Drawing on the existing evidence on the effects of election frequency, we argue that the increase in the number of elective institutions has depressed the global voter turnout.

Figure 1: Evolution of Voter Turnout in National Elections 1945-2017

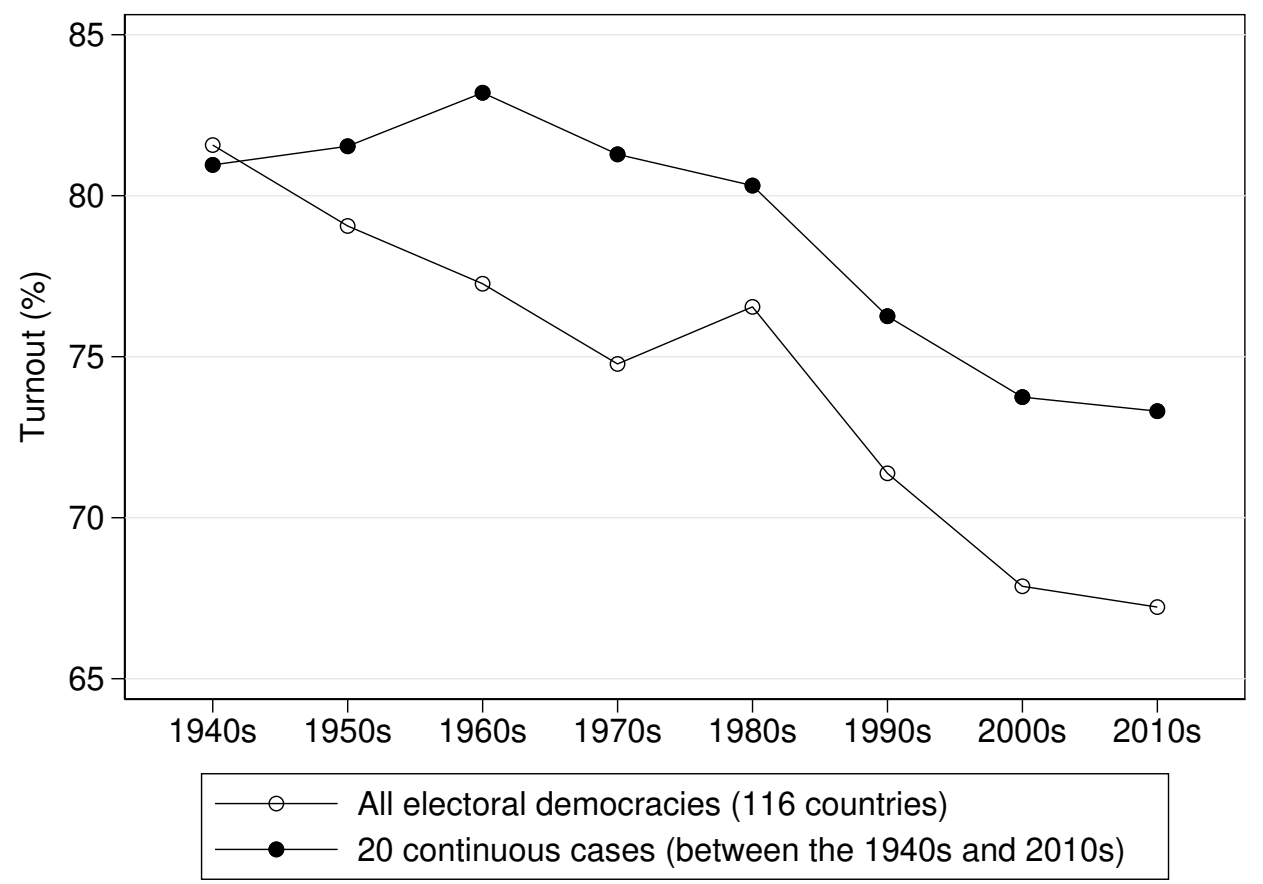

Note: The figure draws on the first rounds of legislative (lower-house) and presidential elections. Voter turnout is measured as \% of registered voters. For sources and further details see the Data \& Methods section.

The empirical contribution of this article consists in testing our two hypotheses, as well as alternative explanations, in large-scale analyses that combine evidence from the aggregated and individual levels. In total, the analyzed data span 1,421 national elections and 314,071 individual

\footnotetext{
${ }^{9}$ Nevitte 1996; Inglehart 1999.
} 
observations from high-quality post-electoral surveys. Moreover, besides testing the different hypotheses, the present study explicitly estimates the weight of their contribution to the global decline in voter turnout.

The empirical section proceeds in three steps. First, we put all the major hypotheses to the test in what we believe is the most comprehensive cross-national analysis of voter turnout to date. This analysis employs an original exhaustive data set of democratic legislative and presidential elections held across the globe between 1945 and 2017. It shows that, by contrast to other explanations, the generational and elective institutions hypotheses receive empirical support across a variety of model specifications and additional robustness checks. In the second step, we focus on the generational hypothesis and test it directly at the individual level using survey data from the four waves of the Comparative Study of Electoral Systems as well as national election studies from Britain, Canada, and the United States. This second analysis also fully supports the generational explanation and provides no evidence in favor of competing alternatives. Moreover, the estimated magnitude of generational differences in voter turnout is, interestingly, similar to that observed in the first analysis. Finally, in the third step, we estimate the contributions of our key factors (generational replacement and rising number of elective institutions) to the global decline by calculating counter-factual voting rates. Altogether, these findings contribute to a better understanding of the current transformation of representative democracy and the challenges it faces.

\section{Existing Explanations}

The most intuitive explanation of why turnout has declined pertains to citizen discontent. Political analysts often assume that the growing number of abstainers reflects citizen dissatisfaction with politics. However, the political science literature does not support this view, neither theoretically nor empirically. Theoretically, it is not clear why dissatisfaction should demobilize rather than mobilize voters or why these effects should not cancel out. ${ }^{10}$ Empirically, there is little evidence that satisfaction declined over the past decades. ${ }^{11}$ Moreover, Ezrow and Xezonakis found that, contrary to conventional expectations, democratic satisfaction (and not dissatisfaction) could be detrimental to voter turnout. ${ }^{12}$ Ultimately, research using micro-level panels reveals that the relationship between democratic satisfaction and voter turnout is reversed. Kostelka and Blais demonstrated that, while pre-election satisfaction is unrelated to voter turnout, post-election satisfaction is generally stronger among voters thanks to the legitimizing effect of elections and a boost of satisfaction in the victorious camp. ${ }^{13}$

In the political science literature, one of the first influential explanations of the global decline in voter turnout relates to group mobilization. Gray and Caul argue that falling membership rates in trade unions and (mainly left-wing) political parties, observed in most established democracies,

\footnotetext{
${ }^{10}$ Pacek, Pop-Eleches, and Tucker 2009; Ezrow and Xezonakis 2016.

${ }^{11}$ Norris 2011; van Ham and Thomassen 2017.

${ }^{12}$ Ezrow and Xezonakis 2016.

${ }^{13}$ Kostelka and Blais 2018.
} 
weakened the mobilization of peripheral voters. ${ }^{14}$ However, while lower membership in political organizations naturally does not help voter turnout, the magnitude of this effect is likely to be small. ${ }^{15}$ Moreover, today, it may be at least partly compensated by modern mobilization techniques (including social media). ${ }^{16}$

Franklin suggests two main causes why voter turnout has declined: transformation of party competition and voting age reforms. ${ }^{17}$ As regards party competition, the argument goes that voter turnout declined because elections became less decisive as party systems gradually fragmented in the post-1960s. This greater fragmentation leads to more coalition cabinets and a weaker correspondence between the outcome of the election and the composition of the government.

The second cause of the decline in voter turnout is the lowering of the voting age below 21 years, which occurred in most established democracies around the mid-1970s. According to Franklin, lowering the voting age increases abstention in the first elections citizens face, which has implications for their long-term propensity to vote. When compared to first-time voters aged 21 and over, those 18 to 20 years old are less likely to socialize in the habit of voting. The progressive replacement of cohorts who made their first decision after 21 years of age by those socialized earlier results in an overall decline in turnout. A weak point of this explanation is that it does not take into account the variety of situations in which young adults live, which reflects, among others, the job market and welfare state arrangements. In a number of countries where turnout declined strongly, especially in Southern Europe, many of those 18 to 20 years old live with their parents which should protect them from the negative effect of the voting age reform. In contrast, in Northern Europe where voter turnout declined the least, youngsters often leave their families early on thanks to generous welfare schemes and a healthy situation on the job market. ${ }^{18}$

Solt used survey data to demonstrate that income inequality may depress electoral participation and, in particular, the engagement of the lowest income categories. ${ }^{19}$ As inequality has risen in recent decades, ${ }^{20}$ this factor may have contributed to the global voter decline. Yet, two caveats are in order. Theoretically, inequality may be mobilizing when it is seized by political parties. ${ }^{21}$ Empirically, most studies using aggregated voter turnout have not found support for the negative effect of income inequality. ${ }^{22}$ It thus seems that the role of income inequality in participation is "more complex than has often been articulated" 23 .

Finally, several studies suggest that a major source of decline is economic globalization. ${ }^{24}$ Ac-

\footnotetext{
${ }^{14}$ Gray and Caul 2000. See also Radcliff and Davis 2000, Leighley and Nagler 2007, and Heath 2007.

${ }^{15}$ Franklin 2004, 18.

${ }^{16}$ See Bond et al. 2012; Teresi and Michelson 2015.

${ }^{17}$ Franklin 2004.

${ }^{18}$ For a comparison of young adults' mobility, see Eurostat 2018.

${ }^{19}$ Solt 2008, 2010.

${ }^{20}$ Piketty 2014.

${ }^{21}$ Polacko et al. 2021.

${ }^{22}$ Arzheimer 2008; Fumagalli and Narciso 2012; Stockemer and Scruggs 2012; Stockemer and Parent 2014; Polacko et al. 2021.

${ }^{23}$ Polacko et al. 2021, 5; see also Stockemer 2017, 9.

${ }^{24}$ Steiner 2010; Steiner and Martin 2012; Marshall and Fisher 2015; Karp and Milazzo 2016.
} 
cording to this account, increased economic integration and capital mobility constrain government policy, which makes national elections less relevant. The strength of this account is that it can, in theory, explain the global nature of the decline. However, economic globalization is accompanied with a rise in the prominence of cultural issues. And parties that oppose the principles of economic and cultural openness are able to gather considerable support and influence policy outcomes, ${ }^{25}$ raising turnout in some social groups ${ }^{26}$ and countries ${ }^{27}$. Therefore, whether and by how much economic globalization depresses voter turnout remains an open question. At the empirical level, several studies ${ }^{28}$ found support for the negative effect of globalization, and party competition depolarization on turnout. By contrast, Aaskoven conducted three different types of analysis and found little evidence of fiscal constraints' negative effect on voter turnout. ${ }^{29}$

In sum, there are several promising explanations but none of them is free of caveats. Some of these explanations (in particular the economic globalization hypothesis) are "macro - macro" accounts and do not provide supporting evidence from individual-level research. By contrast, the hypotheses presented in the next section build heavily on findings at the individual level.

\section{Theory and Hypotheses}

This section presents and further develops two explanations. The first suggests that the decline is due to generational replacement. While it capitalizes on valuable insights from earlier works, it fundamentally departs from the existing literature in that it attributes the causal mechanism of generational change to economic affluence. This has important implications for the empirical tests of the generational account as well as for our understanding of the ultimate causal factors that depress voting rates. The second explanation is institutional and points out a rising number of elective institutions across the democratic world. Although it is clear from the existing research that this institutional trend may be detrimental to participation rates, this factor has been curiously overlooked in the explanation of the global voter turnout dynamics.

\section{Emergence of Affluent Generations}

Researchers have observed for long that, in established democracies, voter turnout tends to be quite stable, oscillating only by a few percentage points from one election to another. ${ }^{30}$ This stability seems to stem from the fact that, once individuals get politically and electorally socialized, which typically occurs by the time they reach their late $20 \mathrm{~s}$, their propensity to vote tends to remain relatively stable through the rest of their lifetime. ${ }^{31}$ While some works interpret this stability as a

\footnotetext{
${ }^{25}$ Kriesi et al. 2006; Abou-Chadi and Krause 2018; Im et al. 2019.

${ }^{26}$ Immerzeel and Pickup 2015.

${ }^{27}$ Leininger and Meijers, n.d.

${ }^{28}$ Steiner 2010; Steiner and Martin 2012; Marshall and Fisher 2015.

${ }^{29}$ Aaskoven 2021.

${ }^{30}$ Blais 2007.

${ }^{31}$ Miller and Shanks 1996; Plutzer 2002.
} 
sign of a habit, ${ }^{32}$ others argue that the stability in voting rather reflects stability in those attitudes that drive the decision to vote such as political interest. ${ }^{33}$ In any case, the relative stability in the individual propensity to vote suggests that major trends in voter turnout occur primarily through generational replacement as new cohorts replace older ones.

Accordingly, a large number of studies of individual-level voter turnout have discovered generational differences between electorally more active older cohorts and less active younger cohorts. ${ }^{34}$ Among these studies, Blais and Rubenson present evidence from the most diverse set of countries. ${ }^{35}$ Studying longitudinal survey data from eight established democracies, they show that individuals born after 1960 vote at significantly lower rates than earlier generations when age and period effects are controlled for. They also demonstrate that the generation difference disappears once two key political attitudes are controlled for: civic duty and external efficacy. In other words, the post-1960 cohort vote less than their predecessors because they have a weaker sense of duty and lower efficacy.

These results support the view that generational differences in attitudes may be one of the causes, if not the main cause, of the gradual decline in voting rates around the world. However, the main limitation of such an explanation is that the deep causes of the generational difference in political attitudes remain so far unknown. Most of the aforementioned studies, which typically focus on individual countries, interpret the differences between generations in terms of country-specific historical events and periods. This means that the generational differences are seen as products of the changing socio-political climate in the countries under study. However, a slightly different, though largely compatible, interpretation is arguably more compelling.

Given that similar effects are observed across democracies located in different sub-regions of the developed world with contrasting political trajectories, ${ }^{36}$ the generational differences are unlikely to primarily reflect these countries' (or their sub-regions') political or historical singularities. ${ }^{37}$ Instead, they should stem from what these countries have in common, which is clearly economic development and its corollaries such as education, access to information, and the weakening of traditional social hierarchies. This alternative interpretation is fully compatible with a broad stream of literature ${ }^{38}$ that draws on Ronald Inglehart's pioneering work ${ }^{39}$ and shows that economic affluence produces significant cultural change. This is because affluence radically transforms social lifestyles and changes the socialization environment in which individuals develop

\footnotetext{
${ }^{32}$ Campbell et al. 1960, 92; Franklin 2004; Dinas 2012; Smets and Neundorf 2014; Coppock and Green 2016; Rapeli, Mattila, and Papageorgiou 2020.

${ }^{33}$ Prior 2010, 765.

${ }^{34}$ Miller and Shanks 1996; Lyons and Alexander 2000; Putnam 2000; Wattenberg 2003; Clarke et al. 2004; Rubenson et al. 2004; Wass 2007; Wattenberg 2011; Tiberj 2018; for more nuanced or contrasting findings see Gallego 2009; Konzelmann, Wagner, and Rattinger 2012; Linek and Petrúšek 2016.

${ }^{35}$ Blais and Rubenson 2013.

${ }^{36}$ For instance, Blais and Rubenson (2013) study Great Britain, Canada, Denmark, Germany, the Netherlands, Norway, Spain, Sweden, and the United States.

${ }^{37}$ Nevertheless, these singularities may, of course, contribute to potential country-specific divergences from the common trend.

${ }^{38}$ Dalton 2008; Norris 2011; Welzel and Inglehart 2011; Klingemann 2014.

${ }^{39}$ Inglehart 1977.
} 
their values and attitudes. Historical research has meticulously documented how the emergence of an "age of affluence" in the late 1950s and early 1960s transformed western societies. It created a world in which youth no longer had to help the family with subsistence and, instead, developed an autonomous culture with distinct values and norms. ${ }^{40}$

An important aspect of this cultural transformation is a generational decline in deference to authority and social norms. ${ }^{41}$ Since the social norm of participation (i.e., the feeling that voting is a civic duty) is one of the key reasons why citizens vote, ${ }^{42}$ the observed cultural change is likely to have depressed new generations' propensity to vote. This would explain the aforementioned generational differences in voter turnout rates observed across a variety of countries. This theory is corroborated by more general studies on political participation, which observe that, in contrast to their older counterparts, new generations consider citizenship more as a right than a duty and increasingly prefer direct forms of participation (such as protests or boycotts) to voting. ${ }^{43}$

Affluence, therefore, produces an environment in which electoral abstention is significantly less stigmatizing. This should exert the strongest effect among the less educated citizens, who are less interested in politics and who have a low intrinsic motivation to vote. It is indeed those citizens whose participation has declined the most in European democracies. ${ }^{44}$ Similarly to education, ${ }^{45}$ affluence thus exerts a different effect at the micro and macro levels. Whereas micro-level affluence is associated with participation, macro-level affluence (and the resulting social change) starts depressing overall participation levels when the country reaches an advanced level of economic development.

If this theory is correct, similar generational differences should be observed in most electoral democracies when they reach levels of economic development comparable to those observed in the West around the early 1960s. In other words, this theory implies that new cohorts of voters that were born and socialized in relative societal economic affluence, which we hence call as "affluent" in the rest of the manuscript, progressively reduce the global turnout rate. It should be emphasized that many members of the affluent cohorts are not at all individually well-off in terms of assets or income. What matters is the global socialization context experienced by the different cohorts.

This theory is about lifestyles that are a product of long-term economic transformation, not about the ebbs and flows of the economy. Since economic slowdowns in developed countries do not make children join the workforce in their early teen years and do not eradicate youth culture and autonomy, our theory implies that they do not stop or reverse the process of generational change. We thus do not expect that the post-1970 economic slowdown, or the 2008 economic cri-

\footnotetext{
${ }^{40}$ Judt 2006.

${ }^{41}$ Nevitte 1996; Inglehart 1999, see also Sutcliffe-Braithwaite 2018.

${ }^{42}$ Riker and Ordeshook 1968; Blais 2000; Blais and Daoust 2020.

${ }^{43}$ Dalton 2008; Coffé and Lippe 2010. At the same time, protesting and other elite-challenging activities presumably do not compensate for the decline in voting. The existing research shows that, at the individual-level, protesting is positively associated with voting, and that those who abstain typically do not protest (Strømsnes 2009; Nový 2014; van Deth 2020).

${ }^{44}$ Armingeon and Schädel 2015; Dassonneville and Hooghe 2017.

${ }^{45}$ Persson 2015.
} 
sis would have halted the generational decline in the propensity to vote in economically developed democracies. This theory is inspired by earlier economic, ${ }^{46}$ political ${ }^{47}$ sociological,${ }^{48}$ and histori$\mathrm{cal}^{49}$ research that explicitly describes the late 1950s and early 1960s as an "age of affluence".

Hypothesis 1 The share of cohorts that grew up in relative economic affluence is negatively associated with voter turnout.

\section{Institutional Change}

In the past decades, citizens' requests for greater participation in government resulted in institutional reforms that have significantly increased the number of times citizens are invited to vote in most electoral democracies. Elections have proliferated because of decentralization, regional (i.e., European) integration, frequent use of referendums, introduction of directly elected presidencies, or shorter terms of office. For instance, in France, in the three years before the 1978 legislative election, citizens could participate on average in three elections. Thirty years later, before the 2017 legislative election, this number was multiplied by three ( 9 votes instead of 3 ) and, in addition, millions of citizens voted in open presidential primaries organized by several political parties. ${ }^{50}$ Interestingly, the 2017 legislative election recorded the lowest turnout in France's post-1945 history. In other countries, the expansion of voting opportunities, has been less dramatic but, for example, in the European Union member states, the number of elected institutions increased on average by approximately $34 \%$ between the $1960 \mathrm{~s}$ and $2010 \mathrm{~s} .{ }^{51}$

This phenomenon has so far passed unnoticed in the literature on the global decline in voter turnout. This is surprising since there are theoretical reasons and empirical findings that support the negative effect of election frequency on voting rates. Moreover, a high number of elective institutions is often advanced to explain why voter turnout is exceptionally low in countries such as the United States and Switzerland. ${ }^{52}$

The detrimental effects of election frequency on participation may be manifold.$^{53}$ Some voters are likely to perceive the increasing participatory demands as unrealistic and feel that, if they vote in one election, they have fulfilled their duty and are entitled to abstain in the following election. Second, more elections typically means more campaigning time and greater strain on party resources. While additional public funding may be available in some cases, the contributions and availability of party supporters usually cannot be significantly expanded and need to be pooled across the increasing number of elections. More generally, the effectiveness of party mobilization

\footnotetext{
${ }^{46}$ Galbraith 1958.

${ }^{47}$ Lane 1965.

${ }^{48}$ Goldthorpe et al. 1968.

${ }^{49}$ Judt 2006.

${ }^{50}$ Kostelka 2017b.

${ }^{51}$ The average number of elected institutions increased from 4.1 to 5.4. See the Methods section for more details on the data.

${ }^{52}$ Boyd 1986, 95; Teixeira 1992, 15 \& 54; Rosenstone and Hansen 1993, 187; Lijphart 1997, 8.

${ }^{53}$ Boyd 1981; Kostelka et al. 2020.
} 
appeals is presumably inversely proportional to the frequency of mobilization. The more often voters get mobilized, the less powerful is the mobilization message. Third, the creation of new elective institutions reduces the importance of preexisting institutions. As long as preexisting and new types of elections are held separately, voters see fewer benefits than before from participating in the preexisting type of elections.

Empirically, most existing studies ${ }^{54}$ find a substantial and statistically significant negative effect of election frequency on voting rates. However, these studies typically do not explicitly connect the rise in election frequency with falling participation rates. Therefore, there is yet no empirical evidence that this factor significantly contributes to the puzzle of the global voter decline. ${ }^{55} \mathrm{We}$ explicitly hypothesize that the general rise in the number of electoral institutions has depressed voter turnout around the world.

Hypothesis 2 The rising number of elective institutions is negatively associated with voter turnout.

In what follows, we conduct two types of empirical analyses. Analysis 1 tests our two hypotheses and the existing explanations on a large comparative data set of post-1945 national elections. Analysis 2 focuses on the generational accounts and tests them against both comparative (the Comparative Study of Electoral Systems) and country-specific (the American, Canadian, and British election studies) survey data. In addition, the last empirical section estimates the contributions of our two key factors to the decline by calculating counter-factual voting rates that would be observed today had those factors remained unchanged since the 1960s.

\section{Analysis 1}

\section{Data \& Methods}

We built an original data set of all the first rounds of national (legislative and presidential) electoral contests meeting democratic standards ${ }^{56}$ that were held between 1945 and 2017, which in total includes 1421 elections. ${ }^{57}$ Using this dataset, we run regression analyses with voter turnout measured

\footnotetext{
${ }^{54}$ See e.g., Boyd 1981, 1986, n.d.; Teixeira 1992, 54-55; Norris 2002; Rallings, Thrasher, and Borisyuk 2003; Ezrow and Xezonakis 2016; Garmann 2017; Kostelka et al. 2020.

${ }^{55}$ For an exception limited to European democracies, see Kostelka et al. 2020.

${ }^{56}$ The selection criterion is Polity IV $\geq 6$, see Marshall 2017.

${ }^{57}$ Some elections that fulfill the selection criteria on Polity IV are not included since their data on voter turnout are unavailable or clearly unreliable. We collected data from printed source (Nohlen, Krennerich, and Thibaut 1999; Nohlen, Grotz, and Hartmann 2001; Nohlen 2005; Nohlen and Stöver 2010) and from the following sources (accessed in July and August 2018) for the most recent elections: www.electionguide.org, www.ipu.org, http://africanelections. tripod.com, http://psephos.adam-carr.net, www.electproject.org. All included elections are listed in the Supplementary Material (Kostelka and Blais 2021).
} 
as the percentage of registered voters that cast a vote ${ }^{58}$ as the dependent variable. To operationalize the decline in voter turnout, our analyses include decade dummy variables. This allows for a nonlinear trend. Our expectation is to reduce the magnitude of these dummies' coefficients through the inclusion of substantive independent variables. The Supplementary Material shows that our main results are robust to the inclusion of linear (year) and quadratic (year squared) time trends.

The operationalization of Hypothesis 1 requires a certain level of affluence from which newly born cohorts develop values that are less conducive to electoral participation. We choose the real GDP per capita of Great Britain in 1960 (\$12,000 in 2011 U.S. dollars) for several reasons. ${ }^{59}$ First, British households experienced a significant improvement in their standards of living in the 1950s. These developments motivated early analyses in value and attitudinal change such as the Affluent Worker study ${ }^{60} .{ }^{61}$ More generally, around 1960, Great Britain was the most developed large country in Western Europe and it was at the forefront of Europe's cultural transformation, which in most other European countries started only later in the 1960s or early 1970s. ${ }^{62}$ Second, Clark and colleagues documented the existence of the generational divide in voter turnout and civic duty between pre-1960 and post-1960 cohorts using data from the British Election Study. ${ }^{63}$ Third, Grasso and colleagues choose practically the same cutting point (1959) and, analyzing entirely different data (the annual British Social Attitudes Survey), found similar generational differences in political participation. ${ }^{64}$

The choice of this benchmark implies that, in North America, which was largely spared the damage of the Second World War and enjoyed high growth rates in the early 1940s, the value change started significantly earlier (e.g., in 1941 in the United States) than in Europe. But this corresponds well both to earlier operationalizations of affluence ${ }^{65}$ and the results of the available generational studies. With regard to the latter, for example, Miller and Shanks find that "New Deal cohorts", who entered the U.S. electorate until 1964 (i.e., were born until the early 1940s), vote at higher rates than "Post-New Deal cohorts". ${ }^{66}$ In most West European countries, the generational divide starts later in the 1960 s or 1970 s (see the Supplementary Material for a full list). ${ }^{67}$ To estimate the age composition of the electorates, we draw on the data of the U.N. population division of

\footnotetext{
${ }^{58}$ The only exception is the United States where, following earlier studies, we use voter turnout in terms of the voting-eligible population (McDonald and Popkin 2001; McDonald 2018). One of the key advantages of both voterregistered and voting-eligible population turnout is that, unlike voting-age population turnout, it is unaffected by the rising influx of refugees and immigrants observed in some established democracies.

${ }^{59}$ The country GDP levels come from Bolt et al. 2018.

${ }^{60}$ Goldthorpe et al. 1968.

${ }^{61}$ Goldthorpe et al. (1968) did not find much change in the political attitudes and behavior of the enriched working class. From the perspective of Hypothesis 1, this is not surprising as the change should come through generational replacement and not through a period effect.

${ }^{62}$ Judt 2006, 377.

${ }^{63}$ Clarke et al. 2004.

${ }^{64}$ Grasso et al. 2019.

${ }^{65}$ For example, when discussing different eras in the U.S. socio-economic history, Lane (1965) described the post1941 period as an "age of affluence", consisting of a 1942-1950 preliminary stage and a full post-1950 stage.

${ }^{66}$ Miller and Shanks 1996.

${ }^{67}$ Kostelka and Blais 2021.
} 
the United Nations, ${ }^{68}$ which covers the $1940-2015$ period. ${ }^{69}$ For each election, the resulting variable Affluent Generations indicates the share of cohorts born in or after the country-specific cutting year $^{70}$ (i.e., when the real GDP reached the British level of 1960). ${ }^{71}$ The variable varies from 0 to 0.91 (the United States in 2014). The Supplementary Material presents the full descriptive statistics for this and all other variables. ${ }^{72}$

Hypothesis 2 is operationalized through a variable Elective Institutions, which corresponds to the sum of elective institutions in each country. It considers the presence of the following seven items: transnational elective institution (i.e., the European Parliament), head of state, lower chamber of parliament, upper chamber of parliament, regional level of government, local level of government, and nationwide referendum (at least one held in the five previous years). The information comes mostly from the V-dem dataset ${ }^{73}$ and the number of institutions varies between 1 (e.g., Czechoslovakia in 1946) and 7 (Slovenia after 2000). ${ }^{74}$ The variable was recoded to vary from 0 to 1 .

As regards alternative interpretations, the variables TU Membership and Party Membership operationalize the group mobilization hypothesis. TU Membership corresponds to the share of trade union membership in the working population. ${ }^{75}$ Party Membership was calculated by dividing the membership of the winning party by the size of the total population. ${ }^{76}$ The variable Majority Status measures the decisiveness of party competition and corresponds to the absolute value of the difference between $50 \%$ and the vote share of the election winner. ${ }^{77}$ Vote at 18 operationalizes voting age

\footnotetext{
${ }^{68}$ United Nations 2017.

${ }^{69}$ The data set gives the population age composition in 5-year age intervals and, thus, we had to assume even age distribution within each interval. See the Supplementary Material for details.

${ }^{70}$ In five cases, the country entered the GDP database only after having reached $\$ 12,000$ and the cutting year had to be estimated through extrapolation. Removing those cases from the analysis has no effect on the substantive results reported below. See the Supplementary Material (Note on Affluent Generations) for details.

${ }^{71}$ In a few countries, the level of development reached the threshold and then declined. In those cases, Affluent Generations are those who were born and spend more than half of their youth (i.e., at least 10 years) above the threshold.

${ }^{72}$ Kostelka and Blais 2021.

${ }^{73}$ Coppedge et al. 2017.

${ }^{74}$ The downside of this indicator is that some of the elections may be held concurrently, which reduces the negative effect of the number of elective institutions. We partially control for this by including a dummy variable for concurrent legislative and presidential elections in all our analyses. Furthermore, we conduct two robustness checks. The first (Model A13 in Table 2 in the Supplemental Materials) shows that European Parliament elections, which have been conducted since 1979 and typically held separately from legislative or presidential contests, are negatively associated with legislative and presidential turnout. For the second robustness check, we were able to collect the full election schedule and adjust the Elective Institutions variable for all types of simultaneous contests in 218 national elections in 20 countries. The correlation between the adjusted and non-adjusted form of the variable is 0.94 . In the regression analysis (Model A14), the adjusted variable yields the expected strongly negative and statistically significant regression coefficient. This suggests that the estimates displayed in our main analyses are robust.

${ }^{75}$ The data comes from the OECD (https://stats.oecd.org/, accessed on 21/07/2018).

${ }^{76}$ Party membership draws on the MAPP dataset (van Heute and Paulis 2016) where we interpolated data for missing years. Given that party membership is usually not available for all parties in an election, we focus on winning parties.

${ }^{77}$ The election winner is the party or candidate that received the largest vote share.
} 
reforms and gives the share of the electorate that became eligible to vote at 18 years of age. ${ }^{78}$ The role of income inequality is explored via the variable Gini (disp. income), which corresponds to the Gini index of inequality in household disposable income from the Standardized World Income Inequality Database ${ }^{79}$. Two variables test the direct and indirect effects of globalization. First, like in Marshall and Fisher's study, ${ }^{80}$ the variable FDI Flows measures the volume of foreign investment flows. ${ }^{81}$ Second, following Steiner and Martin, ${ }^{82}$ the variable Left/Right Polarization gauges the polarization of party competition. It corresponds to the standard deviation of political parties' positions on the left/right scale ${ }^{83}$ in the Manifesto Project data ${ }^{84}$.

In the full model specification, we control for the most important macro-level predictors of voter turnout as identified in the scientific literature. ${ }^{85}$ Voter turnout is higher in those countries where voting is compulsory and where electoral compulsion is enforced. ${ }^{86}$ We thus create two dummies (Compulsory Voting and Compulsory Voting Enforced), which are coded as one respectively when voting is made compulsory by law (or the constitution) and when abstention is sanctioned (at least in rare cases). We include a dummy variable Presidential Election to allow for variation across election types. ${ }^{87}$ Another dummy Concurrent Election takes the value of one when presidential and legislative elections are held jointly. This should increase the benefit of voting, and consequently boost voter turnout. ${ }^{88}$ In terms of party (or candidate) competition, another factor to consider - in addition to Majority Status - is closeness, also known as the margin of victory. Our variable Closeness corresponds to the difference in vote share between the first two parties or candidates. The larger the value of this measure, the less uncertain the election outcome and the lower the voting rate. ${ }^{89}$

In the analyses restricted to legislative elections, we control for the possibility that some elec-

\footnotetext{
${ }^{78}$ Like in the case of the share of affluent generations, we rely on the UN data on the countries' age distribution in the population and the dates of voting age reforms from electoral handbooks and official sources.

${ }^{79}$ Solt 2020.

${ }^{80}$ Marshall and Fisher 2015.

${ }^{81}$ We test exactly the same operationalization as Marshall and Fisher (2015), which is the absolute value of a logarithmic transformation of FDI flows $x$ expressed in terms of GDP. Before the transformation, the original value is increased by one so that the logarithmic function does not approach $-\infty$ when FDI flows get close to zero (see Equation 1). The original data come from the World Bank.

$$
\text { Variable FDI Flows }= \begin{cases}-\ln (-x+1) & \text { if } \mathrm{x} x<0 \\ \ln (x+1) & \text { if } \mathrm{x} x \geq 0\end{cases}
$$

${ }^{82}$ Steiner and Martin 2012.

${ }^{83}$ The unit of observation is a party system, and each party's contribution is weighted by its vote share. The robustness checks presented in the Appendix also test party polarization on the economic and cultural axes as conceptualized in Camia and Caramani 2012.

${ }^{84}$ Volkens et al. 2018.

${ }^{85}$ Geys 2006; Stockemer 2017.

${ }^{86}$ Fornos, Power, and Garand 2004.

${ }^{87}$ As our analysis uses fixed effects (see below), the dummy essentially tests the role of election type in those semi-presidential or presidential political systems where legislative and presidential elections are held separately.

${ }^{88}$ Pacek, Pop-Eleches, and Tucker 2009.

${ }^{89}$ Blais 2000.
} 
toral systems foster participation. ${ }^{90}$ We include dummies for proportional, majoritarian, mixed, and other (e.g., single transferable vote) electoral systems as distinguished in the V-dem data set. Since voter turnout in new democracies may be affected by the processes of democratization and democratic consolidation, ${ }^{91}$ we allow for specific time trends in new democracies. For mutually exclusive categories of pre-1974, post-1974, and post-communist new democracies, we coded three democratization variables that range from 15 (1st year of democracy) to 0 (after the 16th year of democracy). ${ }^{92}$ We originally controlled for the level of economic development (GDP per capita in the 2011 prices), but the variable was never statistically significant. This is probably due to our inclusion of country dummies (see below) and the restriction of our analysis to countries meeting democratic standards, which tend to be economically developed. ${ }^{93}$ Given that the variable is not available for some country-years, we show the analyses with GDP per capita (entered as both linear and quadratic terms) only in the Supplementary Material. These analyses yield the same substantive results as those presented in the next subsection.

The time-series-cross-sectional nature of the data requires special care in the specification of regression models since the results could suffer from unit heterogeneity, auto-correlation, contemporaneous correlation, and non-stationarity. ${ }^{94}$ Concerning unit heterogeneity, we opt for a "within" model by applying country fixed effects. This is the standard approach in the social sciences. ${ }^{95}$ Moreover, this choice fits particularly well with our research question since, in this paper, we are interested in over-time change and not in the explanation of cross-national variation in the absolute levels of turnout. ${ }^{96}$ The statistical tests applied to our preferred model (Model O below) also indicate the presence of serial correlation (but neither non-stationarity nor contemporaneous correlation). ${ }^{97}$ Since our panels are unbalanced and the data is cross-sectionally dominated, we cluster standard errors by country. ${ }^{98}$ We show in the Supplementary Material that our results are robust to

\footnotetext{
${ }^{90}$ Stockemer 2015.

${ }^{91}$ Kostelka 2015, 2017a.

${ }^{92} \mathrm{We}$ follow the conceptualization and results from Kostelka 2017a where the period of 16 years roughly corresponds to the first five democratic elections. By the 6th election, voter turnout in new democracies typically stabilizes and does not differ from established democracies. Any shift from negative to positive values on Polity IV qualifies as a democratic transition for this variable (but, as explained before, our data set includes only elections where Polity IV $\geq 6$ ).

${ }^{93}$ In developed countries, further increases in development are unlikely to boost voter turnout through progress in population literacy or election logistics (e.g. infrastructure etc.). This is confirmed in one of our robustness checks. When we use a random effects specification, the coefficient of GDP becomes positive and highly statistically significant (see Table SM1 in the Supplementary Material).

${ }^{94}$ Wilson and Butler 2007.

${ }^{95}$ Allison 2009.

${ }^{96}$ The choice of the fixed effects model is also suggested by Hausman's specification test $(\mathrm{H} 0=$ no systematic difference between the fixed and random model specifications, $\mathrm{p}<0.001$ ). As our data are stationary (see Footnote 97), the fixed-effect estimation is also more efficient than a first-difference alternative (Wooldridge 2010, Section 10.7.1).

${ }^{97}$ We applied the tests suggested in Wooldridge 2010 for autocorrelation $(\mathrm{H} 0=$ no first-order autocorrelation, $\mathrm{p}$ $<0.05$ ), in Baltagi 2008 for non-stationarity ( $\mathrm{H} 0=$ panels are non-stationary, $\mathrm{p}<0.001$ ), and contemporaneous correlation in Pesaran 2004 ( $\mathrm{H} 0=$ no contemporaneous correlation, $\mathrm{p}>0.1$, estimate for a sub-sample of countries with a sufficiently large number of election years). In addition, we show in the Appendix that using panel-corrected standard errors (that correct for contemporaneous correlation and AR1 autocorrelation) has no effect on our findings.

${ }^{98}$ Wooldridge 2010, Section 13.8.2.
} 
a range of alternative technical specifications. ${ }^{99}$

\section{Results}

Table 1 presents a general overview of the post-1945 evolution of voting rates. It displays several models that regress voter turnout on decades dummies controlling for election type and for democratization (in those models where new democracies are included). The reference category are elections held since 2010. A positive coefficient associated with a decade dummy indicates that turnout was higher in that decade than nowadays. We consider all democratic elections (Model A), legislative elections (B), presidential elections (C), established democracies with enforced compulsory voting (D), established democracies without compulsory voting (E), and 18 established democracies without compulsory voting that held elections both in the 1960 s and 2010s (F). ${ }^{100}$ In all cases but one (Model D), we observe a clear negative trend in voter turnout. The table demonstrates that the decline in voting is not specific to an election type (see models B and C) and that it is not due to an increase in the number of democratic countries (Model F). Conversely, the results of Model D show that, when compulsory voting is enforced and voters may be legally prosecuted for abstention, voter turnout remains remarkably stable in time since most citizens vote in all elections. Countries that enforce compulsory voting are thus clearly not concerned by our research question and are removed from the remaining analyses. ${ }^{101}$

To prevent the following analyses from being affected by factors specific to regime change, like many earlier studies we restrict our principal analyses to established democracies. ${ }^{102}$ At the same time, we demonstrate below that our main results hold even in a pooled analysis of established and new democracies that do not enforce compulsory voting (see Model R in Table 3).

Before testing Hypotheses 1 and 2, we focus on the other explanations of voter decline in Table 2. All models include the political and institutional controls, whose regression coefficients are mostly statistically significant and in the expected direction. Voter turnout is higher when voting is compulsory (even if not enforced) or when two elections (presidential and legislative) are held concurrently. Participation also increases when the gap between the first two competitors diminishes (Closeness) or when the winner gets close to the absolute majority (Majority Status). The latter two variables simultaneously operationalize the party competition hypothesis but the comparison of the decade dummies' regression coefficients between Model E and Models G-K demonstrates that, at best, they account for a small share of the decline. The remaining suspects are tested in turn. ${ }^{103}$ Unexpectedly, none of them receives support from the data. Left-right polarization, party

\footnotetext{
${ }^{99}$ Kostelka and Blais 2021.

${ }^{100}$ Only some of these countries were consolidated democracies before 1960 and thus the 1940s and 1950s estimates should be interpreted with caution as they may be affected by a different composition of the sample. The list of countries is available in the note below Figure 4.

${ }^{101}$ We remove only those elections in which compulsory voting was enforced. For example, the post-1967 Dutch elections are kept in the analyses as the Netherlands removed compulsory voting in 1967.

${ }^{102}$ Altogether we remove 660 elections because they were held in new democracies or countries with enforced compulsory voting. Additional 61 elections are removed because of missing data on some of the key independent variables. The remaining models are thus run usually on 700 elections or fewer depending on data availability.

${ }^{103}$ The number of observations varies from model to model because of data availability.
} 
Table 1: Evolution of Voter Turnout 1945-2017

\begin{tabular}{|c|c|c|c|c|c|c|}
\hline & $\begin{array}{c}\text { A } \\
\text { All } \\
\text { elections }\end{array}$ & $\begin{array}{c}\text { B } \\
\text { All } \\
\text { Legislative elections }\end{array}$ & $\begin{array}{c}\text { C } \\
\text { All } \\
\text { Presidential elections }\end{array}$ & $\begin{array}{c}\text { D } \\
\text { Established dem. } \\
\text { Enforced CV }\end{array}$ & $\begin{array}{l}\mathrm{E} \\
\text { Established dem. } \\
\text { No enforced CV }\end{array}$ & $\begin{array}{c}\mathrm{F} \\
\text { Establishe dem. } \\
18 \text { cases }(1960-2010)\end{array}$ \\
\hline $1940 \mathrm{~s}$ & $7.36(2.28)^{* *}$ & $8.23(2.28)^{* * *}$ & $4.31(4.40)$ & $0.05(1.50)$ & $3.07(3.28)$ & $3.63(3.33)$ \\
\hline $1950 \mathrm{~s}$ & $8.81(1.97)^{* * *}$ & $9.55(1.87)^{* * *}$ & $7.19(4.43)$ & $0.18(1.54)$ & $5.03(2.11)^{*}$ & $5.57(2.22)^{*}$ \\
\hline $1960 \mathrm{~s}$ & $9.11(1.42)^{* * *}$ & $9.37(1.41)^{* * *}$ & $9.02(2.98)^{* *}$ & $-0.72(1.78)$ & $8.24(1.39)^{* * *}$ & $8.78(1.47)^{* * *}$ \\
\hline $1970 \mathrm{~s}$ & $7.29(1.75)^{* * *}$ & $7.78(1.62)^{* * *}$ & $7.31(3.96)^{+}$ & $2.64(2.73)$ & $7.27(1.38)^{* * *}$ & $7.85(1.47)^{* * *}$ \\
\hline $1980 \mathrm{~s}$ & $7.68(1.49)^{* * *}$ & $7.97(1.37)^{* * *}$ & $7.05(2.83)^{*}$ & $0.09(2.04)$ & $6.43(1.39)^{* * *}$ & $7.25(1.36)^{* * *}$ \\
\hline $1990 \mathrm{~s}$ & $4.45(1.38)^{* *}$ & $4.59(1.23)^{* * *}$ & $5.07(2.28)^{*}$ & $-3.92(3.44)$ & $2.92(1.16)^{*}$ & $3.63(1.27)^{*}$ \\
\hline $2000 \mathrm{~s}$ & $1.13(0.96)$ & $1.04(0.90)$ & $1.73(1.59)$ & $0.55(1.36)$ & $0.01(0.80)$ & $0.41(1.18)$ \\
\hline Presidential Election & $1.00(0.89)$ & & & $1.13(0.88)$ & $1.98(1.38)$ & $2.25(2.78)$ \\
\hline Pre-1974 Democratization & $0.12(0.17)$ & $0.19(0.19)$ & $-0.47(0.36)$ & & & \\
\hline Post-1974 Democratization & $-0.10(0.10)$ & $-0.07(0.11)$ & $-0.09(0.16)$ & & & \\
\hline Post-Communist Democratization & $-0.33(0.14)^{*}$ & $-0.36(0.16)^{*}$ & $-0.31(0.20)$ & & & \\
\hline Constant & $66.47(0.85)^{* * *}$ & $67.32(0.84)^{* * *}$ & $64.56(1.35)^{* * *}$ & $86.84(1.57)^{* * *}$ & $65.65(0.68)^{* * *}$ & $67.83(1.03)^{* * *}$ \\
\hline Country FE & Yes & Yes & Yes & Yes & Yes & Yes \\
\hline $\mathrm{N}$ & 1421 & 1034 & 387 & 140 & 700 & 373 \\
\hline R2 (within) & 0.12 & 0.16 & 0.10 & 0.15 & 0.16 & 0.24 \\
\hline
\end{tabular}

Note: OLS regression. Clustered standard errors by country in parentheses. Significance levels: ${ }^{+} p<0.1,{ }^{*} p<0.05,{ }^{* *} p<0.01,{ }^{* * *} p<0.001$. 
membership, and FDI flows are statistically insignificant and their sign is in the wrong direction. While trade union membership, vote at 18 , and income inequality have the correct sign, their substantive significance is limited and they do not meet even the most lenient threshold of statistical significance. Clearly, in the present comprehensive data set, there is no evidence that group mobilization, voting-age reforms, income inequality, or economic globalization provide the solution to the puzzle of voter decline.

We turn to Hypotheses 1 and 2 in Table 3. Models $M$ to $O$ test the variables Affluent Generations and Elective Institutions separately and jointly on the baseline sample of 700 elections from Model E. Models $\mathrm{P}$ to $\mathrm{R}$ run additional tests respectively on legislative elections (only), the 18 stable established democracies from Model $\mathrm{F}$ in Table 1, and all elections (in both new and old democracies) without enforced compulsory voting. In all models, both hypotheses receive strong support from the data. The related variables are statistically and substantively significant and have the correct sign. The larger the share of affluent cohorts or the larger the number of elective institutions, the lower voter turnout.

We present additional analyses in the Supplementary Material showing that the current results hold when, inter alia, we test finer operationalizations of the elective institutions hypothesis on subsets of our data set, control for per capita GDP and GDP growth, enter different operationalizations of time, use random effects (instead of fixed effects), or apply panel-corrected standard errors (instead of clustered standard errors).

\section{Analysis 2}

\section{Data \& Methods}

In the second analysis, we study in greater detail the generational explanation. To provide further evidence, we conduct a series of logistic regressions of individual-level voter turnout using several data sets. We mainly employ the four available waves of the Comparative Study of Electoral Systems. ${ }^{104}$ We replicate the key results using long-running national studies. In addition to the existing cumulative data set of the American National Election Study (ANES, 1948-2016), we use freshly aggregated data from the British Election Study (BES, 1964-2017) and Canadian Election Study (CES, 1965-2015). ${ }^{105}$

It is well-known that the study of generational effects is fraught with difficulty because of their perfect collinearity with the confounding combination of age and period effects (generation $=$ period - age $)$. This identification problem can be addressed only through theoretically-based assumptions. ${ }^{106}$ Following Persson and colleagues, ${ }^{107}$ we apply a two-level hierarchical model (in-

\footnotetext{
${ }^{104}$ The Comparative Study of Electoral Systems 2020. Like in Analysis 1, we restrict our analyses to countries that do not enforce compulsory voting.

${ }^{105}$ See the Supplementary Material for a full list of included studies and elections.

${ }^{106}$ Glenn 1976; Bell and Jones 2018.

${ }^{107}$ Persson, Wass, and Oscarsson 2013.
} 
Table 2: Test of Alternative Explanations Suggested in the Literature

\begin{tabular}{|c|c|c|c|c|c|c|}
\hline & $\begin{array}{l}\mathrm{G} \\
\text { Established dem. } \\
\text { No enforced CV }\end{array}$ & $\begin{array}{l}\mathrm{H} \\
\text { Established dem. } \\
\text { No enforced CV }\end{array}$ & $\begin{array}{l}\text { I } \\
\text { Established dem. } \\
\text { No enforced CV }\end{array}$ & $\begin{array}{l}\text { J } \\
\text { Established dem. } \\
\text { No enforced CV }\end{array}$ & $\begin{array}{l}\mathrm{K} \\
\text { Established dem. } \\
\text { No enforced CV }\end{array}$ & $\begin{array}{c}\mathrm{L} \\
\text { Established dem } \\
\text { No enforced CV }\end{array}$ \\
\hline $1940 \mathrm{~s}$ & & & $2.56(3.38)$ & & & $8.21(2.65)^{* *}$ \\
\hline $1950 \mathrm{~s}$ & & & $3.18(3.26)$ & & & $8.07(2.28)^{* *}$ \\
\hline $1960 \mathrm{~s}$ & $8.25(1.60)^{* * *}$ & $9.12(2.79)^{* *}$ & $6.32(2.70)^{*}$ & $8.09(1.05)^{* * *}$ & & $8.99(1.74)^{* * *}$ \\
\hline $1970 \mathrm{~s}$ & $7.24(2.13)^{* *}$ & $9.76(2.33)^{* * *}$ & $5.51(2.39)^{*}$ & $6.61(1.75)^{* * *}$ & $7.04(1.65)^{* * *}$ & $9.06(1.79)^{* * *}$ \\
\hline $1980 \mathrm{~s}$ & $6.24(2.15)^{* *}$ & $7.09(1.82)^{* * *}$ & $5.29(1.89)^{* *}$ & $5.78(1.51)^{* * *}$ & $6.32(1.47)^{* * *}$ & $7.38(1.70)^{* * *}$ \\
\hline $1990 \mathrm{~s}$ & $3.37(1.59)^{*}$ & $3.67(1.62)^{*}$ & $2.24(1.36)$ & $3.26(1.17)^{* *}$ & $3.55(1.16)^{* *}$ & $4.88(1.41)^{* *}$ \\
\hline $2000 \mathrm{~s}$ & $0.66(0.94)$ & $0.37(1.22)$ & $-0.09(0.83)$ & $0.69(0.73)$ & $0.18(0.78)$ & $1.27(1.01)$ \\
\hline Presidential Election & $-0.54(2.78)$ & & $0.46(1.25)$ & & $1.04(1.23)$ & \\
\hline Majority Status & $-0.15(0.06)^{*}$ & $-0.18(0.13)$ & $-0.14(0.06)^{*}$ & $-0.13(0.05)^{*}$ & $-0.13(0.06)^{*}$ & $-0.18(0.07)^{* *}$ \\
\hline Closeness & $-0.15(0.06)^{*}$ & $-0.17(0.08)^{+}$ & $-0.11(0.04)^{* *}$ & $-0.10(0.04)^{* *}$ & $-0.11(0.04)^{* *}$ & $-0.14(0.05)^{* *}$ \\
\hline Concurrent Election & $15.16(2.29)^{* * *}$ & & $9.51(2.88)^{* *}$ & $9.39(2.89)^{* *}$ & $9.35(2.75)^{* *}$ & $15.24(0.24)^{* * *}$ \\
\hline Compulsory Voting & $9.47(4.76)^{+}$ & $3.56(1.80)^{+}$ & $8.40(3.63)^{*}$ & $4.69(1.10)^{* * *}$ & $3.93(1.10)^{* * *}$ & $8.16(4.27)^{+}$ \\
\hline \multicolumn{7}{|l|}{ Group Mobilization: } \\
\hline TU Membership & $0.04(0.06)$ & & & & & \\
\hline Party Membership & & $-0.12(0.15)$ & & & & \\
\hline \multicolumn{7}{|l|}{ Voting Age Reforms } \\
\hline Vote at 18 & & & $-2.77(3.99)$ & & & \\
\hline \multicolumn{7}{|l|}{ Income Inequality: } \\
\hline Gini (disp. income) & & & & $-24.95(18.39)$ & & \\
\hline \multicolumn{7}{|l|}{ Globalization: } \\
\hline FDI Flows & & & & & $0.30(0.38)$ & \\
\hline Left/Right Polarization & & & & & & $0.00(0.05)$ \\
\hline Constant & $67.08(2.04)^{* * *}$ & $76.82(3.29)^{\text {*** }}$ & $67.88(3.29)^{* * *}$ & $74.16(6.99)^{* * *}$ & $65.01(1.30)^{* * *}$ & $71.34(2.11)^{* * *}$ \\
\hline Country FE & Yes & Yes & Yes & Yes & Yes & Yes \\
\hline $\mathrm{N}$ & 399 & 182 & 697 & 638 & 607 & 356 \\
\hline R2 (within) & 0.46 & 0.50 & 0.31 & 0.22 & 0.26 & 0.45 \\
\hline
\end{tabular}

Note: OLS regression. Clustered standard errors by country in parentheses. Countries with enforced compulsory voting are excluded. Significance levels: ${ }^{+} p<$ $0.1,{ }^{*} p<0.05,{ }^{* *} p<0.01,{ }^{* * *} p<0.001$. 
Table 3: Test of Generational and Institutional Change

\begin{tabular}{|c|c|c|c|c|c|c|}
\hline & $\begin{array}{c}\mathrm{M} \\
\text { Established } \\
\text { democracies }\end{array}$ & $\begin{array}{c}\mathrm{N} \\
\text { Established } \\
\text { democracies }\end{array}$ & $\begin{array}{c}\mathrm{O} \\
\text { Established } \\
\text { democracies }\end{array}$ & $\begin{array}{c}\mathrm{P} \\
\text { Established dem. } \\
\text { leg. elections }\end{array}$ & $\begin{array}{c}\mathrm{Q} \\
\text { Established dem. } \\
18 \text { cases (1960-2010) }\end{array}$ & $\begin{array}{c}\mathrm{R} \\
\text { All } \\
\text { democracies }\end{array}$ \\
\hline $1940 \mathrm{~s}$ & $0.97(2.60)$ & $3.59(2.48)$ & $-0.56(2.90)$ & $0.18(3.46)$ & $0.31(3.07)$ & $0.85(2.52)$ \\
\hline $1950 \mathrm{~s}$ & $1.63(2.33)$ & $4.02(2.09)^{+}$ & $-0.06(2.46)$ & $0.53(3.02)$ & $0.22(2.17)$ & $2.21(2.58)$ \\
\hline $1960 \mathrm{~s}$ & $4.94(1.91)^{*}$ & $7.15(1.40)^{* * *}$ & $3.42(2.09)$ & $2.85(2.59)$ & $3.45(1.73)^{+}$ & $4.47(2.03)^{*}$ \\
\hline 1970s & $4.57(2.01)^{*}$ & $6.15(1.54)^{* * *}$ & $3.06(2.20)$ & $2.80(2.60)$ & $3.14(2.00)$ & $2.70(2.26)$ \\
\hline $1980 \mathrm{~s}$ & $4.50(1.75)^{*}$ & $6.01(1.41)^{* * *}$ & $3.80(1.82)^{*}$ & $3.34(2.14)$ & $3.45(1.64)^{+}$ & $4.50(1.80)^{*}$ \\
\hline $1990 \mathrm{~s}$ & $1.74(1.23)$ & $2.58(1.08)^{*}$ & $1.33(1.23)$ & $1.42(1.30)$ & $0.94(1.29)$ & $3.33(1.30)^{*}$ \\
\hline $2000 s$ & $-0.23(0.76)$ & $0.01(0.75)$ & $-0.33(0.76)$ & $-0.65(0.79)$ & $-1.00(1.02)$ & $0.09(0.86)$ \\
\hline Presidential Election & $0.70(1.27)$ & $0.71(1.29)$ & $0.69(1.29)$ & & $-1.28(2.58)$ & $0.37(0.97)$ \\
\hline Majority Status & $-0.13(0.06)^{*}$ & $-0.13(0.06)^{*}$ & $-0.13(0.05)^{*}$ & $-0.12(0.07)^{+}$ & $-0.19(0.06)^{* *}$ & $-0.13(0.06)^{*}$ \\
\hline Closeness & $-0.10(0.04)^{* *}$ & $-0.11(0.04)^{* *}$ & $-0.10(0.04)^{* *}$ & $-0.11(0.04)^{* *}$ & $-0.15(0.04)^{* *}$ & $-0.04(0.03)$ \\
\hline Concurrent Election & $9.65(2.80)^{* * *}$ & $9.62(2.83)^{* *}$ & $9.62(2.81)^{* *}$ & $11.95(2.77)^{* * *}$ & $15.10(2.02)^{* * *}$ & $8.08(2.17)^{* * *}$ \\
\hline Compulsory Voting & $7.92(3.06)^{*}$ & $7.98(3.79)^{*}$ & $6.99(2.93)^{*}$ & $6.92(3.22)^{*}$ & $8.11(3.79)^{*}$ & $13.01(3.69)^{* * *}$ \\
\hline \multicolumn{7}{|l|}{ Hypotheses 1 and 2: } \\
\hline Affluent Generations & $-7.03(3.06)^{*}$ & & $-8.25(3.05)^{* *}$ & $-8.21(3.78)^{*}$ & $-6.82(2.08)^{* *}$ & $-7.57(3.41)^{*}$ \\
\hline Elective Institutions & & $-8.57(3.36)^{*}$ & $-10.33(3.30)^{* *}$ & $-11.63(3.04)^{* * *}$ & $-9.37(3.31)^{*}$ & $-11.70(4.20)^{* *}$ \\
\hline Pre-1974 Democratization & & & & & & $0.20(0.18)$ \\
\hline Post-1974 Democratization & & & & & & $-0.04(0.14)$ \\
\hline Post-Communist Democratization & & & & & & $-0.15(0.15)$ \\
\hline Proportional Elect. System & & & & $-1.61(2.40)$ & & \\
\hline Mixed Elect. System & & & & $-1.96(1.50)$ & & \\
\hline Other Elect. System & & & & $3.05(1.17)^{*}$ & & \\
\hline Constant & $67.88(1.56)^{* * *}$ & $70.96(2.58)^{* * *}$ & $74.38(2.93)^{* * *}$ & $78.25(3.87)^{* * *}$ & $77.93(3.14)^{* * *}$ & $72.33(3.22)^{* * *}$ \\
\hline Country FE & Yes & Yes & Yes & Yes & Yes & Yes \\
\hline $\mathrm{N}$ & 700 & 700 & 700 & 527 & 373 & 1103 \\
\hline R2 (within) & 0.32 & 0.32 & 0.33 & 0.44 & 0.55 & 0.22 \\
\hline
\end{tabular}

Note: OLS regression. Clustered standard errors by country in parentheses. Countries with enforced compulsory voting are excluded. Significance levels: ${ }^{+} p<$ $0.1,{ }^{*} p<0.05,{ }^{* *} p<0.01,{ }^{* * *} p<0.001$. 
dividuals nested in elections) after reducing the number of levels through country fixed effects. ${ }^{108}$ Our models assume the presence of broad generational groups identified through dummy variables and, altogether, test three generational schemes. The first scheme operationalizes Hypothesis 1 via a dummy variable Affluent Generations, which identifies those individuals who were born after their country reached the real GDP of $\$ 12,000$ in 2011 dollars. The second scheme tests the voting age hypothesis. The dummy variable Vote at 18 codes as 1 those respondents who became eligible to vote at the age of 18 . Finally, the third scheme delves into generational differences independent of economic development and voting age. It adopts the Pew Research Center's taxonomy, ${ }^{109}$ distinguishing the Silent Generation (respondents born before 1945), Baby-Boomers (1945-1964), Generation X (1965-1980), and Millenials (1981-) who serve as the reference category. While these labels draw on the U.S. experience, the periodization largely reflects global events (the end of the Second World War, the cultural revolts in the 1960s, etc.) and the scheme is routinely used overseas. ${ }^{110}$ Our theory implies that the first scheme (Affluent Generation) provides the most powerful explanation.

All models control for a quadratic function of age in years (i.e., age effects), year of the survey (to operationalize the time trend), and employ election-specific random intercepts to account for the context of each election (i.e., period effects). In addition, while we are primarily interested in the unconditional effects of generational change, ${ }^{111}$ one model specification includes individuallevel and macro-level controls. The individual-level controls comprise dummy variables for gender (ref. category Male), education (Primary), income (Quintile 1), and trade union membership (Not Member). The macro-level controls are all the control variables from Analysis 1 and the Elective Institutions variable. ${ }^{112}$ If Hypothesis 1 is valid and the generational differences are driven by a changing value structure, these controls should not significantly diminish the effect of the generational variables.

\section{Results}

Table 4 displays six regression models. Models S, T, and V test Hypothesis 1 , the voting age hypothesis, and the Pew scheme respectively. Models $\mathrm{U}$ and $\mathrm{W}$ conduct simultaneous tests and, finally, Model X include the controls and Elective Institutions. The regression coefficient of Affluent Generations is substantively and statistically significant and of a similar magnitude in all model specifications. ${ }^{113}$ Likewise, Election Institutions yields the expected negative regression coefficient, which provides additional support for Hypothesis 2. By contrast, Vote at 18 and the Pew-based scheme yield statistically and substantively insignificant coefficients, especially when entered jointly with Affluent Generations. In the rest of the analysis, we thus focus on Hypothesis 1.

\footnotetext{
${ }^{108}$ See Arzheimer 2009.

${ }^{109}$ Pew Research Center 2015.

${ }^{110}$ See e.g., Intergenerational Commission 2018.

${ }^{111}$ This is because only the unconditional effects can reveal how much generational change contributes to the voter decline, which this study aims to explain.

${ }^{112}$ Compulsory voting had to be dropped because of the country fixed effects and a lack of temporal variation.

${ }^{113}$ The Supplementary Material shows that these results are robust to the inclusion of additional individual-level or macro-level controls such as democratic satisfaction or income inequality (see Table 3).
} 
Table 4: Individual-level Analysis (CSES data)

\begin{tabular}{|c|c|c|c|c|c|c|}
\hline & $\begin{array}{c}\mathrm{S} \\
\text { Affluent Generations }\end{array}$ & $\begin{array}{c}\mathrm{T} \\
\text { Vote at } 18\end{array}$ & $\begin{array}{c}\mathrm{U} \\
\text { Simultaneous Test }\end{array}$ & $\begin{array}{c}\mathrm{V} \\
\text { Pew Generations }\end{array}$ & $\begin{array}{c}\text { W } \\
\text { Simultaneous Test }\end{array}$ & $\begin{array}{c}\mathrm{X} \\
\text { All Controls }\end{array}$ \\
\hline \multicolumn{7}{|l|}{ Generational Explanations } \\
\hline Affluent Generations & $-0.25(0.02)^{* * *}$ & & $-0.26(0.02)^{* * *}$ & & $-0.25(0.02)^{* * *}$ & $-0.20(0.03)^{* * *}$ \\
\hline Vote at 18 & & $-0.04(0.02)$ & $0.01(0.02)$ & & & \\
\hline Silent Generation (-1945) & & & & $0.13(0.06)^{*}$ & $0.11(0.06)^{+}$ & \\
\hline Boomers (1946-1964) & & & & $-0.01(0.04)$ & $-0.03(0.04)$ & \\
\hline Generation X (1965-1980) & & & & $-0.05(0.02)^{*}$ & $-0.03(0.02)$ & \\
\hline \multicolumn{7}{|l|}{ Individual-Level Controls } \\
\hline Age & $0.08(0.00)^{* * *}$ & $0.08(0.00)^{* * * *}$ & $0.08(0.00)^{* * *}$ & $0.09(0.00)^{* * *}$ & $0.08(0.00)^{* * *}$ & $0.06(0.00)^{* * *}$ \\
\hline Age $x$ Age & $-0.00(0.00)^{* * *}$ & $-0.00(0.00)^{* * *}$ & $-0.00(0.00)^{* * *}$ & $-0.00(0.00)^{* * *}$ & $-0.00(0.00)^{* * *}$ & $-0.00(0.00)^{* * *}$ \\
\hline Female & & & & & & $-0.06(0.02)^{* * * *}$ \\
\hline Income (Q2) & & & & & & $0.22(0.02)^{* * *}$ \\
\hline Income (Q3) & & & & & & $0.37(0.02)^{* * *}$ \\
\hline Income (Q4) & & & & & & $0.51(0.03)^{* * *}$ \\
\hline Income (Q5) & & & & & & $0.63(0.03)^{\text {*** }}$ \\
\hline High School & & & & & & $0.40(0.02)^{* * *}$ \\
\hline Some College & & & & & & $0.51(0.03)^{* * *}$ \\
\hline College \& Above & & & & & & $0.94(0.03)^{* * *}$ \\
\hline TU membership & & & & & & $0.23(0.02)^{* * *}$ \\
\hline \multicolumn{7}{|l|}{ Macro-Level Controls } \\
\hline Presidential Election & & & & & & $0.75(0.37)^{*}$ \\
\hline Majority Status & & & & & & $-0.02(0.01)^{+}$ \\
\hline Closeness & & & & & & $-0.00(0.01)$ \\
\hline Concurrent Elections & & & & & & $1.00(0.30)^{* * *}$ \\
\hline Elective Institutions & & & & & & $-1.45(0.56)^{* *}$ \\
\hline Year & $0.00(0.01)$ & $-0.00(0.01)$ & $0.00(0.01)$ & $0.00(0.01)$ & $0.00(0.01)$ & $0.01(0.01)$ \\
\hline Constant & $-3.47(16.03)$ & $1.23(16.07)$ & $-3.24(16.03)$ & $-0.82(16.18)$ & $-5.67(16.15)$ & $-10.61(17.31)$ \\
\hline Var (Elections) & $0.18(0.03)^{* * *}$ & $0.18(0.03)^{* * *}$ & $0.18(0.03)^{* * *}$ & $0.18(0.03)^{* * *}$ & $0.18(0.03)^{* * *}$ & $0.17(0.03)^{* * *}$ \\
\hline Country FE & Yes & Yes & Yes & Yes & Yes & Yes \\
\hline $\mathrm{N}$ (individuals) & 184061 & 184061 & 184061 & 184061 & 184061 & 131217 \\
\hline $\mathrm{N}$ (elections) & 116 & 116 & 116 & 116 & 116 & 108 \\
\hline
\end{tabular}

Note: CSES data (waves 1-4). Hierarchical logistic regression with random intercepts for elections and country fixed effects. Significance levels: ${ }^{+} p<0.1,{ }^{*} p<0.05,{ }^{* *} p<0.01,{ }^{* * *} p<0.001$.

Figure 2 graphically illustrates the substantive significance of Affluent Generations. It shows the predicted probability to vote based on Model S from Table 4. ${ }^{114}$ The difference between affluent generations and their elders amounts to nearly 6 percentage points. Interestingly, this magnitude is close to what we observed in the macro-analysis of elections (Analysis 1), where the coefficient of Affluent Generations oscillated around 7 percentage points. Of course, these estimates correspond to the potential maximal effects of generational replacement and not to the amount of the decline in voter turnout generation effects account for. This amount is properly estimated in the next section. But we first further examine the empirical evidence on Hypothesis 1.

To minimize the risk that the result from Model $\mathrm{S}$ is based on random noise and to check the appropriateness of the $\$ 12,000$ benchmark, we replicated the analysis using alternative thresholds of economic affluence ranging from $\$ 6,000$ to $\$ 18,000$. If Hypothesis 1 is correct and there is a generational divide around $\$ 12,000$, the coefficient of Affluent Generations should decline if lower or higher thresholds are chosen. ${ }^{115}$ This is exactly what Figure 3 shows. The substantive signifi-

\footnotetext{
${ }^{114}$ The only difference is that the estimation used for Figure 2 uses data weighted with real voter turnout rates to correct for over-reporting. This allows for a more realistic estimation of the magnitude of the generational difference in voting.

${ }^{115}$ If a lower threshold is chosen, the group of younger, less active generations will include some individuals from the older, active generations. If a higher threshold is chosen, the group of older, active generations will include some individuals from the younger, less active generations. In both cases, the regression coefficient should be weaker.
} 
Figure 2: Generational Difference in the Probability to Vote (CSES data)

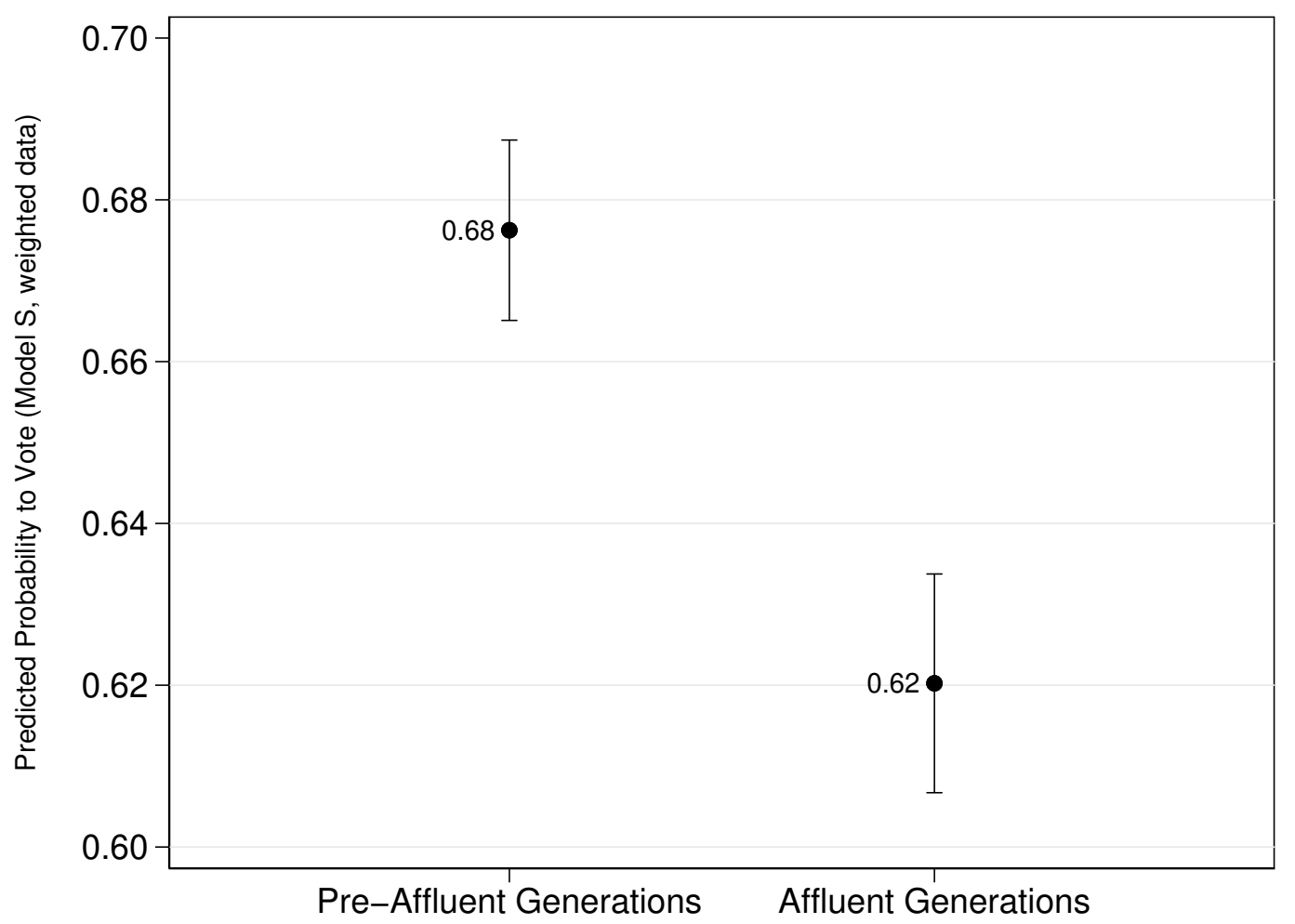

cance of the regression coefficient gradually rises as the value of the threshold approaches $\$ 12,000$, where the coefficient reaches its maximum. The theory-based choice of the $\$ 12,000$ benchmark is thus correct. However, had we chosen any other value in between $\$ 10,000$ and $\$ 14,000$, we would observe similar, albeit slightly weaker results. Clearly, there is a robust relationship between being born in a context of relative affluence and the propensity to abstain.

To further test the robustness of our findings, we replicated Model S using the ANES, CES, and BES datasets, which, inter alia, have the advantage of covering much longer time-spans. ${ }^{116}$ Table 5 shows that, in all three cases, the Affluent Generations variable has the expected sign and is substantively and statistically significant. In terms of predicted probability to vote, there is a generational gap of 3.1, 7.6, and 8.5 points in the U.S., British, and Canadian national elections respectively. In those countries, generational replacement thus may account for most of the decline at the aggregated level, which amounts to 3.6 points in the US presidential elections, 9.3 in the British legislative elections, and 11.2 in the Canadian legislative elections. ${ }^{117}$ This provides further support for Hypothesis 1.

\footnotetext{
${ }^{116}$ Given that these are single-country analyses with a limited number of elections, we follow Blais, Gidengil, and Nevitte (2004) and apply single-level logistic regressions with election fixed effects and standard errors clustered by election.

${ }^{117}$ The declines were calculated based on those elections that are covered by the national election studies (US: 1948-2016; Britain: 1966-2017; Canada: 1965-2015).
} 
Figure 3: Generational Differences (CSES data) - Alternative Thresholds

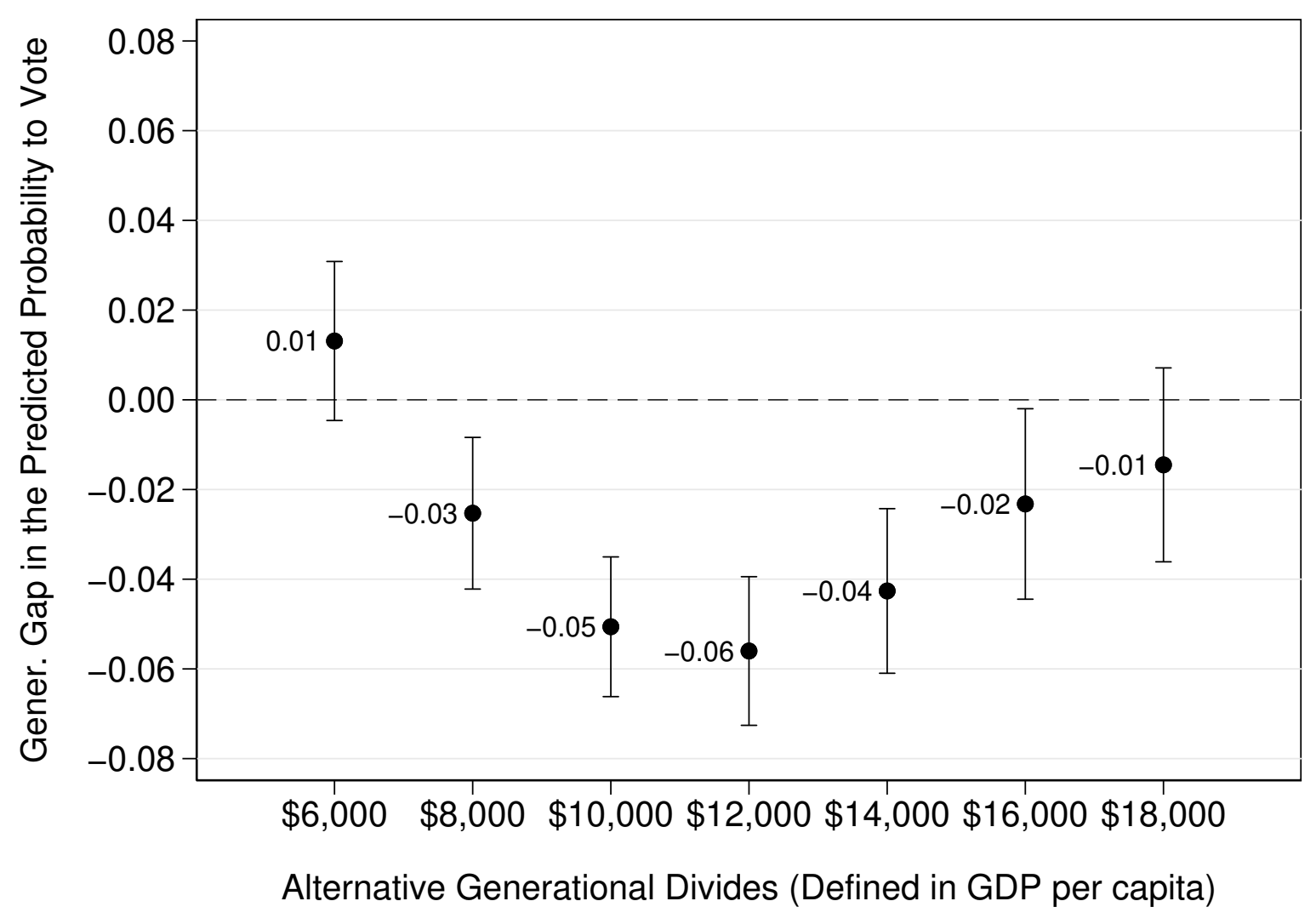

Table 5: Individual-level Analysis (National Election Studies)

\begin{tabular}{lccc}
\hline \hline & ANES & BES & \multicolumn{1}{c}{ CES } \\
\hline Affluent Generations & $-0.13(0.06)^{*}$ & $-0.39(0.08)^{* * *}$ & $-0.41(0.11)^{* * *}$ \\
Age & $0.11(0.01)^{* * *}$ & $0.07(0.01)^{* * *}$ & $0.08(0.01)^{* * *}$ \\
Age x Age & $-0.00(0.00)^{* * *}$ & $-0.00(0.00)^{* * *}$ & $-0.00(0.00)^{* * *}$ \\
Constant & $-1.85(0.16)^{* * *}$ & $-0.11(0.14)$ & $-0.17(0.23)$ \\
\hline Election FE & Yes & Yes & Yes \\
$\mathrm{N}$ & 53021 & 38617 & 38372 \\
Pseudo R2 & 0.08 & 0.05 & 0.04 \\
\hline \hline
\end{tabular}

Note: American National Election Study (1948-2016), British Election Study (1964-2017) and Canadian Election Study (1965-2015) respectively. Single-level logistic regressions with election fixed effects and clustered standard errors by election in parentheses. Significance levels: ${ }^{+} p<0.1,{ }^{*} p<0.05,{ }^{* *} p<0.01$, ${ }^{* * *} p<0.001$.

\section{Quantifying the Sources of Decline}

Analyses 1 and 2 provide evidence for Hypotheses 1 and 2. However, we do not yet know how much of the observed decline these hypotheses explain. To that effect, we move back to the aggregated-level (Analysis 1) and focus on the 18 countries that conducted democratic elections 
both in the 1960s and 2010s. In them, voter turnout declined by 8 points. ${ }^{118}$ We estimate how voter turnout would change if, in the 2010s, the independent variables included in the full regression model (Model Q Table 3) took the values from the 1960s. ${ }^{119}$ We provide two estimations. The first is conservative as it is based on Model Q that includes decade dummies. Their inclusion controls for the time-trend, which eliminates the risk of a spurious correlation but simultaneously may absorb some of the explanatory power of the substantive variables. For the other, liberal estimation, we replicated Model Q without the decade dummies in the regression analysis. This gives more leeway to the substantive variables but, of course, runs the risk of spuriousness in some of the explained variance.

The conservative and liberal estimations are displayed in Figure 4. In both cases, the largest contribution to the decline ( 2.9 and 4.5 points) stems from generational replacement, the share of affluent cohorts having increased from 0 to 0.44 on average between the $1960 \mathrm{~s}$ and $2010 \mathrm{~s}$. Reforms relative to elective institutions, including fewer concurrent elections, come second (1.4 and 1.7 points $),{ }^{120}$ followed by party/candidate competition $(0.5$ and $1 \mathrm{pp}) .{ }^{121}$ Whereas the decline is clearly multi-causal in nature, generational replacement appears to be the most powerful factor. Altogether, the two estimations amount to 4.8 and 7.2 percentage points respectively, which means that the present model accounts for between $60 \%$ and $90 \%$ of the total 8-percentage-point decline. These estimations suggest that our two hypotheses jointly explain a substantial part of the global decline in voter turnout.

\section{Discussion}

We have investigated the causes of the global decline in voter turnout in democracies. For this investigation we have built a data set of more than 1400 national democratic elections held between 1945 and 2017 and we have combined this aggregate analysis with an examination of individual survey data, both cross-nationally (CSES) and longitudinally (in Britain, Canada, and the U.S.). Our results provide no support for the detrimental effects of economic globalization or weakened group mobilization. Nor do we find that lowering the voting age substantially contributed to the decline. Among the prominent explanations advanced in the existing macro-analyses, only the role of majority status in party competition is partly supported. However, shifts in majority status are responsible only for a small share of the decline and are largely compensated by today's more competitive elections. Instead, we find that most of the decline comes from two sources: one cultural and one institutional.

\footnotetext{
${ }^{118}$ This magnitude of the decline (8 points) is slightly lower than the value of the 1960s dummy variable in Model $\mathrm{F}$ in Table 1 ( 8.8 points). This is because our quantification of the decline is based on country-decade averages, which ensures that the weight of each country is the same regardless of how many elections this country held in the given decade.

${ }^{119}$ We predicted voter turnout using the results from Model Q and replacing the 2010s values of the independent variables by those from the 1960 s.

${ }^{120}$ This total contribution combines the effects of the variables Elective Institutions (1.2 or $\left.1.5 \mathrm{pp}\right)$ and Concurrent Elections (0.2 pp in both estimations).

${ }^{121}$ In fact, majority status depressed voter turnout by 1.5 and 1.8 points but this was partially offset by a more competitive character of elections (i.e., smaller values on election closeness, +1 and +0.8 points).
} 
Figure 4: Contributions to the 1960s-2010s Decline in 18 Established Electoral Democracies
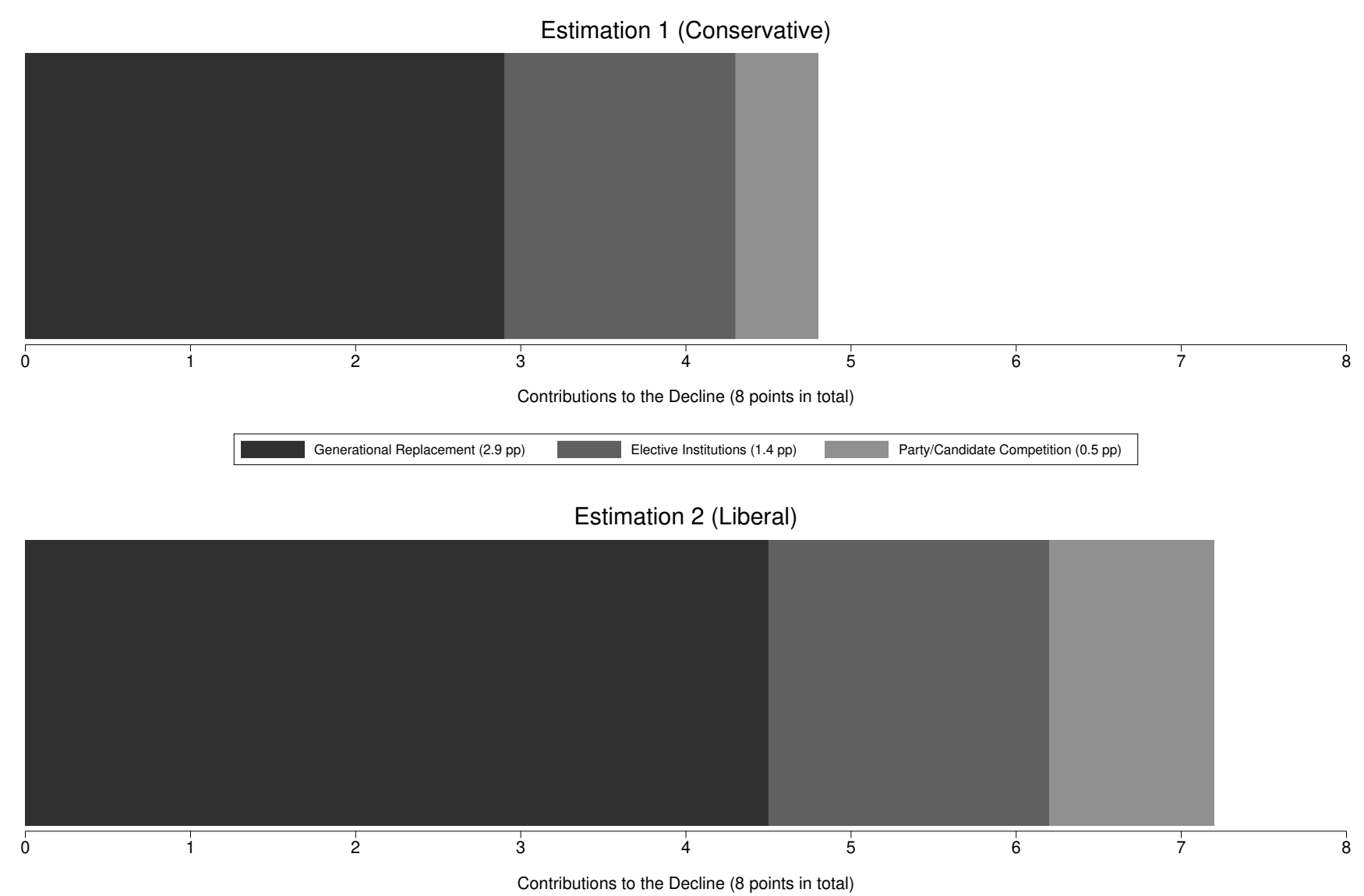

Contributions to the Decline (8 points in total)

Generational Replacement (4.5 pp)

Elective Institutions $(1.7 \mathrm{pp})$

Party/Candidate Competition (1 pp)

Note: The 18 included countries that held democratic elections without enforced compulsory voting in the 1960s and 2010s are: Canada, Costa Rica, Denmark, Finland, France, Germany, India, Ireland, Israel, Italy, Japan, New Zealand, Norway, Sri Lanka, Sweden, Turkey, United Kingdom, the United States. The conservative estimation draws on regression Model Q from Table 3. The liberal estimation employs a replication of Model Q that omits decade dummy variables. 
The generational replacement explanation trumps all other accounts. While the presented evidence is correlational, there are several reasons for being fairly confident about this finding. First, it holds across a large variety of model specifications in the macro-analysis: for various sub-samples of electoral democracies, in the presence of alternative time indicators, or more generic variables (per capita GDP). Second, this finding matches the evidence on generational differences in voting rates from a number of recent micro-level longitudinal studies - panels and rolling cross-sections - that we discussed in the theory section. Third, our own generational analysis of individual-level data, whose design allows for a close inspection of the generational divide, fully corroborates the distinction between affluent cohorts and their older counterparts. Fourth, the patterns of participation that we observe both at the macro- and micro-levels are consistent with the expectation of less duty-based citizenship as described in the literature on value change. ${ }^{122}$

Another factor that is consistently supported in this analysis is the rise in the number of elective institutions. While its contribution is relatively modest when compared to that of generational replacement, it is still more than twice as large as the contribution of party competition. Although this factor has been largely absent in existing accounts of the global decline, this finding empirically supports the widely held views about the reasons for the exceptionally low voter turnout in the United States and Switzerland, and it matches evidence from a number of geographically circumscribed analyses.

The present findings support the existence of an ongoing profound transformation in participation trends in electoral democracies. This transformation is not over yet as, even in those countries that reached the age of affluence early on such as the United States or Canada, affluent cohorts still do not represent the entirety of their respective electorates. Generational replacement may thus, unless off-set by other factors, further reduce participation rates in the years to come. ${ }^{123}$ These findings support some of the central claims of the literature on value change and invite further research into the underlying mechanisms through which economic development affects citizens' sense of civic duty and other relevant values and attitudes.

\section{References}

Aaskoven, Lasse. 2021. "Fiscal Rules and Electoral Turnout." Political Science Research and Methods 9, no. 2: 259-274. doi: 10.1017/psrm.2019.27.

Abou-Chadi, Tarik, and Werner Krause. 2018. "The Causal Effect of Radical Right Success on Mainstream Parties' Policy Positions: A Regression Discontinuity Approach." British Journal of Political Science: 1-19. doi: 10.1017/S0007123418000029.

Aggeborn, Linuz. 2016. "Voter Turnout and the Size of Government." European Journal of Political Economy 43, no. C: 29-40. doi: 10.1016/j.ejpoleco.2016.01.003.

\footnotetext{
${ }^{122}$ Inglehart 1979; Dalton 2008; Welzel and Inglehart 2011; Norris 2011; Klingemann 2014.

${ }^{123}$ It should be emphasized that a future decline is certainly not inevitable. The affluent generations' weaker propensity to participate, which our theory attributes to a lower sense that going to the polls is a civic duty, may be neutralized by partisan polarization, and other political or institutional factors.
} 
Allison, Paul David. 2009. Fixed Effects Regression Models. Los Angeles: Sage.

Armingeon, Klaus, and Lisa Schädel. 2015. "Social Inequality in Political Participation: The Dark Sides of Individualisation.” West European Politics 38, no. 1: 1-27. doi: 10.1080/01402382. 2014.929341.

Arzheimer, Kai. 2009. "Contextual Factors and the Extreme Right Vote in Western Europe, 1980 - 2002." American Journal of Political Science 53, no. 2: 259-275. doi: 10.1111/j.15405907.2009.00369.x.

Arzheimer, Kai. 2008. "Something Old, Something New, Something Borrowed, Something True? A Comment on Lister's 'Institutions, Inequality and Social Norms: Explaining Variations in Participation'." The British Journal of Politics and International Relations 10, no. 4: 681697. doi: 10.1111/j.1467-856x.2008.00336.x.

Avery, James M. 2015. "Does Who Votes Matter? Income Bias in Voter Turnout and Economic Inequality in the American States from 1980 to 2010.” Political Behavior 37, no. 4: 955-976. doi: 10.1007/s11109-015-9302-z.

Baltagi, Badi H. 2008. Econometric Analysis of Panel Data. Édition: 4th Revised edition. Chichester, UK: John Wiley \& Sons Ltd.

Bell, Andrew, and Kelvyn Jones. 2018. "The Hierarchical Age-Period-Cohort Model: Why Does it Find the Results that it Finds?" Quality \& Quantity 52, no. 2: 783-799. doi: 10.1007/s11135017-0488-5.

Blais, André. 2000. To Vote or Not to Vote?: The Merits and Limits of Rational Choice Theory. Pittsburgh: University of Pittsburgh Press, August 3.

Blais, André. 2007. “Turnout in Elections.” In Klingemann, Hans-Dieter, and Russell J. Dalton, eds., The Oxford Handbook of Political Behavior. Oxford: Oxford University Press.

Blais, André, and Jean-François Daoust. 2020. Motivation to Vote. Vancouver: UBC Press.

Blais, André, Ruth Dassonneville, and Filip Kostelka. 2020. "Political Equality and Turnout." In Rohrschneider, Robert, and Jacques Thomassen, eds., The Oxford Handbook of Political Representation in Liberal Democracies. Oxford: Oxford University Press.

Blais, André, Elisabeth Gidengil, and Neil Nevitte. 2004. "Where Does Turnout Decline Come From?” European Journal of Political Research 43, no. 2: 221-236. doi: 10.1111/j.14756765.2004.00152.x.

Blais, André, and Daniel Rubenson. 2013. "The Source of Turnout Decline New Values or New Contexts?" Comparative Political Studies 46, no. 1: 95-117. doi: 10.1177/00104140124530 32.

Bolt, Jutta, Robert Inklaar, Herman de Jong, and Jan Luiten van Zanden. 2018. "Rebasing 'Maddison': New Income Comparisons and the Shape of Long-Run Economic Development. Maddison Project Database, version 2018." Maddison Project Working paper 10. 
Bond, Robert M., Christopher J. Fariss, Jason J. Jones, Adam D. I. Kramer, Cameron Marlow, Jaime E. Settle, and James H. Fowler. 2012. "A 61-Million-Person Experiment in Social Influence and Political Mobilization.” Nature 489, no. 7415: 295-298. doi: 10.1038/nature11421.

Boyd, Richard W. 1981. "Decline of U.S. Voter Turnout: Structural Explanations.” American Politics Quarterly 9, no. 2: 133-159. doi: 10.1177/1532673X8100900201.

Boyd, Richard W. 1986. "Election Calendars and Voter Turnout." American Politics Research 14, no. 1: 89-104. doi: 10.1177/1532673X8601400106.

Boyd, Richard W. "The Effects of Primaries and Statewide Races on Voter Turnout." The Journal of Politics 51, no. 3: 730-739. doi: 10.2307/2131504.

Brody, Richard A. 1978. "The Puzzle of Political Participation in America." In King, Anthony, eds., The New American Politicla System. Washington, D.C.: American Enterprise Institute for Public Policy Research.

Camia, Valeria, and Daniele Caramani. 2012. "Family Meetings: Ideological Convergence within Party Families across Europe, 1945-2009." Comparative European Politics 10, no. 1: 48-85. doi: 10.1057/cep.2011.1.

Campbell, Angus, Philip E. Converse, Warren E. Miller, and Donald E. Stokes. 1960. The American Voter. Chicago: The University of Chicago Press.

Clarke, Harold D., David Sanders, Marianne C. Stewart, and Paul Whiteley. 2004. Political Choice in Britain. Oxford: Oxford University Press.

Coffé, Hilde, and Tanja van der Lippe. 2010. "Citizenship Norms in Eastern Europe.” Social Indicators Research 96, no. 3: 479-496. doi: 10.1007/s11205-009-9488-8.

Coppedge, Michael, John Gerring, Carl Henrik Knutsen, Staffan I. Lindberg, Svend-Erik Skaaning, Jan Teorell, David Altman, et al. 2017. V-Dem [Country-Year/Country-Date] Dataset v8. At https://doi.org/10.23696/vdemcy18,

Coppock, Alexander, and Donald P. Green. 2016. "Is Voting Habit Forming? New Evidence from Experiments and Regression Discontinuities.” American Journal of Political Science 60, no. 4: 1044-1062. doi: 10.1111/ajps.12210.

Dalton, Russell J. 2008. "Citizenship Norms and the Expansion of Political Participation.” Political Studies 56, no. 1: 76-98. doi: 10.1111/j.1467-9248.2007.00718.x.

Dassonneville, Ruth, and Marc Hooghe. 2017. "Voter Turnout Decline and Stratification: QuasiExperimental and Comparative Evidence of a Growing Educational Gap." Politics 37, no. 2: 184-200. doi: 10.1177/0263395716674370.

Dinas, Elias. 2012. "The Formation of Voting Habits." Journal of Elections, Public Opinion and Parties 22, no. 4: 431-456. doi: 10.1080/17457289.2012.718280.

Eurostat. 2018. Bye Bye Parents: When Do Young Europeans Flee the Nest?. At https://ec.europa. eu/, accessed May 15, 2018. 
Ezrow, Lawrence, and Georgios Xezonakis. 2016. "Satisfaction with democracy and voter turnout A temporal perspective." Party Politics 22, no. 1: 3-14. doi: 10.1177/1354068814549335.

Fornos, Carolina A., Timothy J. Power, and James C. Garand. 2004. "Explaining Voter Turnout in Latin America, 1980 to 2000." Comparative Political Studies 37, no. 8: 909-940. doi: $10.1177 / 0010414004267981$.

Franklin, Mark N. 2004. Voter Turnout and the Dynamics of Electoral Competition in Established Democracies since 1945. Cambridge, MA: Cambridge University Press, April 19.

Fumagalli, Eileen, and Gaia Narciso. 2012. "Political Institutions, Voter Turnout, and Policy Outcomes." European Journal of Political Economy 28, no. 2: 162-173.

Galbraith, John Kenneth. 1958. The Affluent Society. New York: Houghton Mifflin.

Gallego, Aina. 2009. "Where Else Does Turnout Decline Come From? Education, Age, Generation and Period Effects in Three European Countries." Scandinavian Political Studies 32, no. 1: 23-44. doi: 10.1111/j.1467-9477.2008.00212.x.

Garmann, Sebastian. 2017. "Election Frequency, Choice Fatigue, and Voter Turnout." European Journal of Political Economy 47: 19-35. doi: 10.1016/j.ejpoleco.2016.12.003.

Geys, Benny. 2006. "Explaining Voter Turnout: A Review of Aggregate-Level Research.” Electoral Studies 25, no. 4: 637-663. doi: 10.1016/j.electstud.2005.09.002.

Glenn, Norval D. 1976. “Cohort Analysts' Futile Quest: Statistical Attempts to Separate Age, Period and Cohort Effects." American Sociological Review 41, no. 5: 900-904. doi: 10.2307/ 2094738.

Goldthorpe, John H., David Lockwood, Frank Bechhofer, and Jenifer Platt. 1968. The Affluent Worker: Industrial Attitudes and Behaviour. 1 edition. London, Cambridge: Cambridge University Press.

Grasso, Maria Teresa, Stephen Farrall, Emily Gray, Colin Hay, and Will Jennings. 2019. "Socialization and Generational Political Trajectories: an Age, Period and Cohort Analysis of Political Participation in Britain." Journal of Elections, Public Opinion and Parties 29, no. 2: 199-221. doi: 10.1080/17457289.2018.1476359.

Gray, Mark, and Miki Caul. 2000. "Declining Voter Turnout in Advanced Industrial Democracies, 1950 to 1997 The Effects of Declining Group Mobilization." Comparative Political Studies 33, no. 9: 1091-1122. doi: 10.1177/0010414000033009001.

Heath, Oliver. 2007. "Explaining Turnout Decline in Britain, 1964-2005: Party Identification and the Political Context." Political Behavior 29, no. 4: 493-516. doi: 10.1007/s11109-0079039-4.

Huntington, Samuel P. 1991. The Third Wave: Democratization in the Late 20th Century. Norman: University of Oklahoma Press.

Im, Zhen Jie, Nonna Mayer, Bruno Palier, and Jan Rovny. 2019. "The "Losers of Automation": A Reservoir of Votes for the Radical Right?” Research \& Politics 6, no. 1: 2053168018822395. doi: $10.1177 / 2053168018822395$. 
Immerzeel, Tim, and Mark Pickup. 2015. "Populist Radical Right Parties Mobilizing 'the People'? The Role of Populist Radical Right Success in Voter Turnout." Electoral Studies 40: 347-360. doi: 10.1016/j.electstud.2015.10.007.

Inglehart, Ronald. 1979. "Political Action: The Impact of Values, Cognitive Level, and Social Background." In Political action : mass participation in five Western democracies, by Samuel H. Barnes, Max Kaase, Klaus R. Allerbeck, Barbara G. Farah, Felix Heunks, Ronald Inglehart, Kent M. Jennings, Hans-Dieter Klingemann, Alan Marsh, and Leopold Rosenmayr, 306343. Beverly Hills, Calif. : Sage Publications.

1999. "Postmodernization Erodes Respect for Authority, But Increases Support for Democracy.” In Critical Citizens: Global Support for Democratic Government, by Pippa Norris, 236256. Oxford University Press, March.

-1977. Silent Revolution: Changing Values and Political Styles Among Western Publics. Princenton: Princeton Univ Press, June.

Intergenerational Commission. 2018. A New Generational Contract: The Final Report of the Intergenerational Commission. At https://www.resolutionfoundation.org/advanced/a- newgenerational-contract/, accessed July 6, 2020.

Judt, Tony. 2006. Postwar: A History of Europe Since 1945. Penguin Books.

Karp, Jeffrey A., and Caitlin Milazzo. 2016. "Globalization and Voter Turnout in Times of Crisis." In Vowles, Jack, and Georgios Xezonakis, eds., Globalization and Domestic Politics. Oxford: Oxford University Press.

Kasara, Kimuli, and Pavithra Suryanarayan. 2015. "When Do the Rich Vote Less Than the Poor and Why? Explaining Turnout Inequality across the World." American Journal of Political Science 59, no. 3: 613-627. doi: 10.1111/ajps.12134.

Klingemann, Hans-Dieter. 2014. "Dissatisfied Democrats. Evidence from Old and New Democracies." In Dalton, Russell J., and Christian Welzel, eds., The Civic Culture Transformed From Allegiant to Assertive Citizens. Cambridge: Cambridge University Press.

Konzelmann, Laura, Corina Wagner, and Hans Rattinger. 2012. "Turnout in Germany in the course of time: Life cycle and cohort effects on electoral turnout from 1953 to 2049." Electoral Studies 31, no. 2: 250-261. doi: 10.1016/j.electstud.2011.11.006.

Kostelka, Filip. 2017a. "Does Democratic Consolidation Lead to a Decline in Voter Turnout? Global Evidence Since 1939.” American Political Science Review 111, no. 4: 653-667. doi: 10.1017/S0003055417000259.

Kostelka, Filip. 2017b. "Plus d'élections équivaut à moins de participation." Le Monde. June 15. At https://www.lemonde.fr/idees/article/2017/06/15/plus-d-elections-equivaut-a-moins-departicipation_5145085_3232.html.

Kostelka, Filip. 2015. “To Mobilise and Demobilise: The Puzzling Decline of Voter Turnout in Post-Communist Democracies." PhD diss., Paris, Institut d'études politiques. 
Kostelka, Filip, and André Blais. 2021. Supplementary material for "The Generational and Institutional Sources of the Global Decline in Voter Turnout”. At https://doi.or/10.1017/tktkt,

Kostelka, Filip, and André Blais. 2018. "The Chicken and Egg Question: Satisfaction with Democracy and Voter Turnout." PS: Political Science and Politics 51, no. 2: 370-376.

Kostelka, Filip, Eva Krejcova, Nicolas Sauger, and Alexander Wuttke. 2020. "Democracy, Votes, and Participation: The Effect of Election Frequency on Voter Turnout." Paper prepared for delivery at the 2020 virtual European Political Science Association Conference, 18-19 June.

Kriesi, Hanspeter, Edgar Grande, Romain Lachat, Martin Dolezal, Simon Bornschier, and Timotheos Frey. 2006. "Globalization and the Transformation of the National Political Space: Six European Countries Compared.” European Journal of Political Research 45, no. 6: 921-956. doi: 10.1111/j.1475-6765.2006.00644.x.

Lane, Robert E. 1965. "The Politics of Consensus in an Age of Affluence." The American Political Science Review 59, no. 4: 874-895. doi: 10.2307/1953211.

Leighley, Jan E., and Jonathan Nagler. 2007. "Unions, Voter Turnout, and Class Bias in the U.S. Electorate, 1964-2004." The Journal of Politics 69, no. 2: 430-441. doi: 10.1111/j.14682508.2007.00541.x.

Leininger, Arndt, and Maurits J Meijers. Forthcoming. "Do Populist Parties Increase Voter Turnout? Evidence From Over 40 Years of Electoral History in 31 European Democracies." Political Studies: 1-21. doi: 10.1177/0032321720923257.

Lijphart, Arend. 1997. "Unequal Participation: Democracy's Unresolved Dilemma.” American Political Science Review 91, no. 1: 1-14. doi: 10.2307/2952255.

Linek, Lukáš, and Ivan Petrúšek. 2016. "What's Past is Prologue, or Is It? Generational Effects on Voter Turnout in Post-Communist Countries, 1990-2013." Electoral Studies 42: 78-90. doi: 10.1016/j.electstud.2016.02.002.

Lyons, William, and Robert Alexander. 2000. "A Tale of Two Electorates: Generational Replacement and the Decline of Voting in Presidential Elections." The Journal of Politics 62, no. 4: 1014-1034. doi: 10.1111/0022-3816.00044.

Marshall, John, and Stephen D. Fisher. 2015. "Compensation or Constraint? How Different Dimensions of Economic Globalization Affect Government Spending and Electoral Turnout." British Journal of Political Science 45, no. 2: 353-389. doi: 10.1017/S0007123413000422.

Marshall, Monty G. 2017. POLITY IV PROJECT: Dataset Users' Manual. At https://www.syste micpeace.org/inscr/p4manualv2016.pdf, accessed May 1, 2018.

Martin, Paul S., and Michele P. Claibourn. 2013. "Citizen Participation and Congressional Responsiveness: New Evidence that Participation Matters." Legislative Studies Quarterly 38, no. 1: 59-81. doi: 10.1111/lsq.12003.

McDonald, Michael P. 2018. National Turnout Rates, 1787-2016. At http://www.electproject.org/ home/voter-turnout/voter-turnout-data, accessed September 9, 2018. 
McDonald, Michael P., and Samuel L. Popkin. 2001. "The Myth of the Vanishing Voter." American Political Science Review 95, no. 4: 963-974.

Miller, Warren E., and J. Merrill Shanks. 1996. The New American Voter. Cambridge: Harvard University Press, October 15.

Nevitte, Neil. 1996. The Decline of Deference: Canadian Value Change in Cross National Perspective. Toronto: University of Toronto Press.

Nohlen, Dieter, ed. 2005. Elections in the Americas: South America. Oxford: Oxford University Press, June 30.

Nohlen, Dieter, Florian Grotz, and Christof Hartmann, eds. 2001. Elections in Asia and the Pacific: The Middle East, Central Asia, and South Asia. Oxford: Oxford University Press.

Nohlen, Dieter, Michael Krennerich, and Bernhard Thibaut, eds. 1999. Elections in Africa: a data handbook. Oxford: Oxford University Press, September 23.

Nohlen, Dieter, and Philip Stöver, eds. 2010. Elections in Europe: A Data Handbook. BadenBaden, Germany: Nomos Verlagsgesellschaft.

Nooruddin, Irfan, and Joel W. Simmons. 2015. "Do Voters Count? Institutions, Voter Turnout, and Public Goods Provision in India." Electoral Studies 37: 1-14. doi: 10.1016/j.electstud.2014. 10.006 .

Norris, Pippa. 2011. Democratic Deficit: Critical Citizens Revisited. New York: Cambridge University Press.

- 2002. Democratic Phoenix: Reinventing Political Activism. Cambridge: Cambridge University Press.

Nový, Michal. 2014. "Electoral and Non-Electoral Participation in the Visegrad Countries Complements or Substitutes?" East European Politics \& Societies 28, no. 4: 863-886. doi: 10. $1177 / 0888325414532496$.

Pacek, Alexander C, Grigore Pop-Eleches, and Joshua A. Tucker. 2009. "Disenchanted or Discerning: Voter Turnout in Post-Communist Countries." The Journal of Politics 71, no. 2: 473-491.

Persson, Mikael. 2015. "Education and Political Participation.” British Journal of Political Science 45, no. 3: 689-703. doi: 10.1017/S0007123413000409.

Persson, Mikael, Hanna Wass, and Henrik Oscarsson. 2013. "The Generational Effect in Turnout in the Swedish General Elections, 1960-2010." Scandinavian Political Studies 36, no. 3: 249269. doi: 10.1111/1467-9477.12005.

Pesaran, Mohammad Hashem. 2004. "General Diagnostic Tests for Cross Section Dependence in Panels." Cambridge Working Papers in Economics, no. 435.

Pew Research Center. 2015. The Whys and Hows of Generations Research. At www.pewresearch. org/politics/2015/09/03/the-whys-and-hows-of-generations-research, accessed July 6, 2020.

Piketty, Thomas. 2014. Capital in the Twenty-First Century. Cambridge, MA: Harvard University Press, March 18. 
Plutzer, Eric. 2002. "Becoming a Habitual Voter: Inertia, Resources, and Growth in Young Adulthood." American Political Science Review 96, no. 1: 41-56. doi: 10.1017/S0003055402004 227.

Polacko, Matthew, Oliver Heath, Michael S Lewis-Beck, and Ruth Dassonneville. 2021. "Policy Polarization, Income Inequality and Turnout.” Political Studies 69, no. 2: 455-477. doi: 10. $1177 / 0032321720906581$.

Prior, Markus. 2010. "You've Either Got It or You Don't? The Stability of Political Interest over the Life Cycle." The Journal of Politics 72, no. 3: 747-766. doi: 10.1017/s0022381610000149.

Putnam, Robert. 2000. Bowling Alone: The Collapse and Revival of American Community. New York: Simon \& Schuster.

Radcliff, Benjamin, and Patricia Davis. 2000. "Labor Organization and Electoral Participation in Industrial Democracies.” American Journal of Political Science 44, no. 1: 132. doi: 10.2307/ 2669299.

Rallings, C., M. Thrasher, and G. Borisyuk. 2003. "Seasonal factors, voter fatigue and the costs of voting." Electoral Studies 22, no. 1: 65-79. doi: 10.1016/S0261-3794(01)00047-6.

Rapeli, Lauri, Mikko Mattila, and Achillefs Papageorgiou. 2020. "Breaking a Habit: The Impact of Health on Turnout and Party Choice." Party Politics 26, no. 2: 133-142. doi: 10.1177/ 1354068817753060 .

Riker, William H., and Peter C. Ordeshook. 1968. "A Theory of the Calculus of Voting." American Political Science Review 62, no. 1: 25-42. doi: 10.2307/1953324.

Rosenstone, Steven J., and John Mark Hansen. 1993. Mobilization, Participation, and Democracy in America. New York: Longman, February 1.

Rubenson, Daniel, André Blais, Patrick Fournier, Elisabeth Gidengil, and Neil Nevitte. 2004. "Accounting for the Age Gap in Turnout." Acta Politica 39, no. 4: 407-421. doi: 10.1057/ palgrave.ap.5500079.

Smets, Kaat, and Anja Neundorf. 2014. "The Hierarchies of Age-Period-Cohort Research: Political Context and the Development of Generational Turnout Patterns." Electoral Studies 33: 41-51. doi: 10.1016/j.electstud.2013.06.009.

Solt, Frederick. 2010. "Does Economic Inequality Depress Electoral Participation? Testing the Schattschneider Hypothesis." Political Behavior 32, no. 2: 285-301. doi: 10.1007/s11109010-9106-0.

Solt, Frederick. 2008. "Economic Inequality and Democratic Political Engagement." American Journal of Political Science 52, no. 1: 48-60. doi: 10.1111/j.1540-5907.2007.00298.x.

Solt, Frederick. 2020. "Measuring Income Inequality Across Countries and Over Time: The Standardized World Income Inequality Database.” Social Science Quarterly 101, no. 3: 11831199.

Steiner, Nils D. 2010. "Economic Globalization and Voter Turnout in Established Democracies." Electoral Studies 29, no. 3: 444 -459. doi: https://doi.org/10.1016/j.electstud.2010.04.007. 
Steiner, Nils D., and Christian W. Martin. 2012. "Economic Integration, Party Polarisation and Electoral Turnout." West European Politics 35, no. 2: 238-265. doi: 10.1080/01402382. 2011.648005 .

Stockemer, Daniel. 2015. "District Magnitude and Electoral Turnout: A Macro-Level Global Analysis.” Acta Politica 50, no. 1: 82-100. doi: 10.1057/ap.2013.35.

Stockemer, Daniel. 2017. "What Affects Voter Turnout? A Review Article/Meta-Analysis of Aggregate Research.” Government and Opposition 52, no. 4: 698-722. doi: 10.1017/gov.2016. 30 .

Stockemer, Daniel, and Stephanie Parent. 2014. "The Inequality Turnout Nexus: New Evidence from Presidential Elections." Politics \& Policy 42, no. 2: 221-245. doi: https://doi.org/10. 1111/polp.12067.

Stockemer, Daniel, and Lyle Scruggs. 2012. "Income Inequality, Development and Electoral Turnout - New Evidence on a Burgeoning Debate.” Electoral Studies 31, no. 4: 764-773. doi: 10. 1016/j.electstud.2012.06.006.

Strømsnes, Kristin. 2009. "Political Consumerism: A Substitute for or Supplement to Conventional Political Participation?” Journal of Civil Society 5, no. 3: 303-314.

Sutcliffe-Braithwaite, Florence. 2018. Class, Politics, and the Decline of Deference in England, 1968-2000. Oxford: Oxford University Press, March.

Teixeira, Ruy A. 1992. The Disappearing American Voter. Washington: Brookings Institution Press.

Teresi, Holly, and Melissa R. Michelson. 2015. "Wired to Mobilize: The Effect of Social Networking Messages on Voter Turnout.” The Social Science Journal 52, no. 2: 195-204. doi: 10.1016/j.soscij.2014.09.004.

The Comparative Study of Electoral Systems. 2020. CSES INTEGRATED MODULE DATASET (IMD) [dataset and documentation]. At www . cses . org, accessed January 26, 2021. doi: 10.7804/cses.imd.2020-12-08.

Tiberj, Vincent. 2018. "Le vote décentré ?” Revue française de science politique 68, no. 5: 821845. doi: 10.3917/rfsp.685.0821.

United Nations, Population Division., Department of Economic and Social Affairs. 2017. World Population Prospects: The 2017 Revision. At https://esa.un.org/unpd/wpp/, accessed May 18, 2018.

van Deth, Jan W. 2020. “Non-Electoral Participation.” In Rohrschneider, Robert, and Jacques Thomassen, eds., The Oxford Handbook of Political Representation in Liberal Democracies. Oxford: Oxford University Press.

van Ham, Carolien, and Jacques Thomassen. 2017. “The Myth of Legitimacy Decline.” In van Ham, Carolien, Jacques Thomassen, Kees Aarts, and Rudy Andeweg, eds., The Myth of Legitimacy Decline: An Empirical Evaluation of Trends in Political Support in Established Democracies. Oxford, England: Oxford University Press. 
van Heute, Emilie, and Emilien Paulis. 2016. MAPP Dataset. At https://zenodo.org/record/61234\# .YLFiJKhKiUk, accessed May 18, 2018. doi: 10.5281/zenodo.61234.

Volkens, Andrea, Pola Lehmann, Theres Matthieß, Nicolas Merz, Sven Regel, and Bernhard Weßels. 2018. The Manifesto Data Collection. Manifesto Project (MRG/CMP/MARPOR). Version 2018a. At https://manifesto-project.wzb.eu/datasets? archived=yes, accessed February 2, 2019. doi: 10.25522/manifesto.mpds.2018a.

Wass, Hanna. 2007. "The Effects of Age, Generation and Period on Turnout in Finland 1975-2003." Electoral Studies 26, no. 3: 648-659. doi: 10.1016/j.electstud.2007.06.002.

Wattenberg, Martin P. 2003. "Electoral Turnout: The New Generation Gap." British Elections \& Parties Review 13, no. 1: 159-173. doi: 10.1080/13689880308413092.

Wattenberg, Martin P. 2011. Is Voting for Young People? 3 edition. Boston: Routledge, October 27.

Welzel, Christian, and Ronald Inglehart. 2011. "Political Culture." In Comparative Politics, by Daniele Caramani (ed.), 311-330. Oxford: Oxford University Press.

Wilson, Sven E, and Daniel M Butler. 2007. "A Lot More to Do: The Sensitivity of Time-Series Cross-Section Analyses to Simple Alternative Specifications." Political Analysis 15, no. 2: 101-123. doi: 10.1093/pan/mp1012.

Wooldridge, Jeffrey M. 2010. Introductory Econometrics: A Modern Approach. 4th ed. Cambridge, MA: MIT Press. 